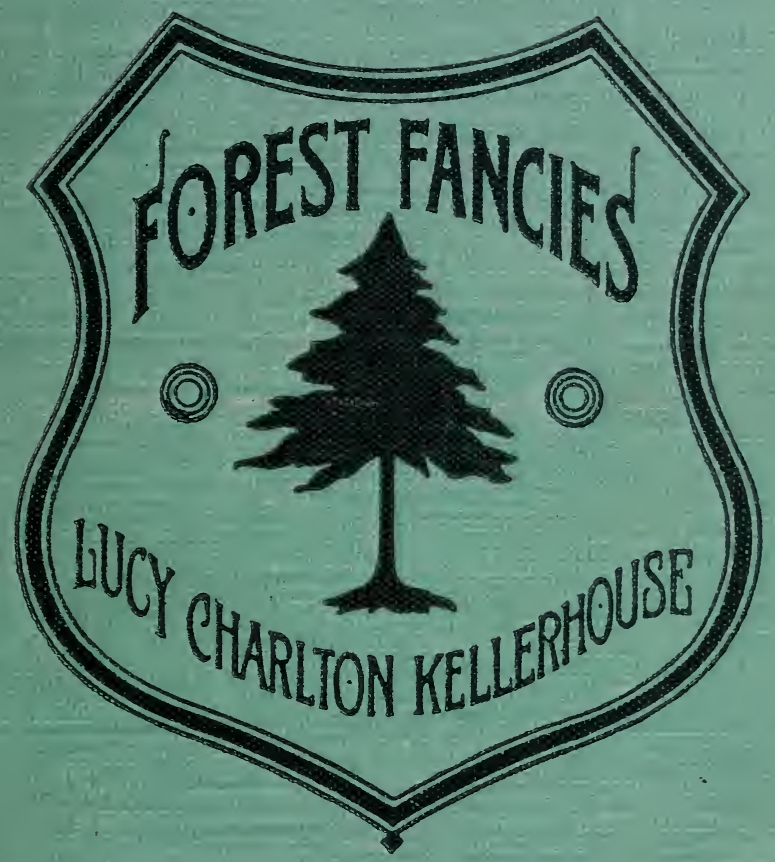




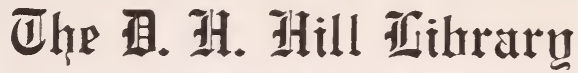

Anrth Carnlina State flniurersity

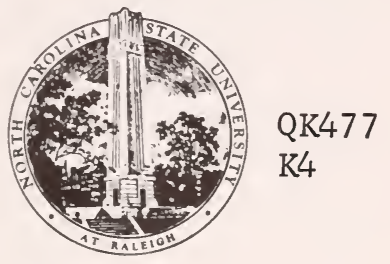

This book was presented by

THE NATIONAL FOREST PRODUCTS ASSOCIATION

. D. C. 
THIS BOOK IS DUE ON THE DATE INDICATED BELOW AND IS SUBJECT TO AN OVERDUE FINE AS POSTED AT THE CIRCULATION DESK.

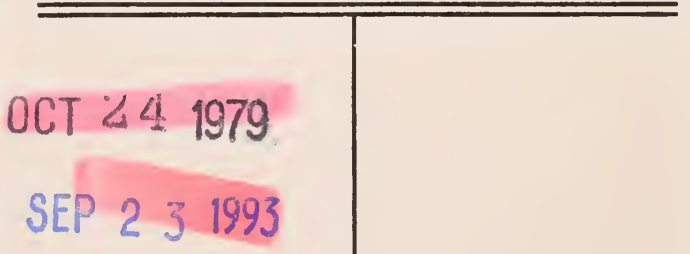





\section{FOREST FANCIES}


. 


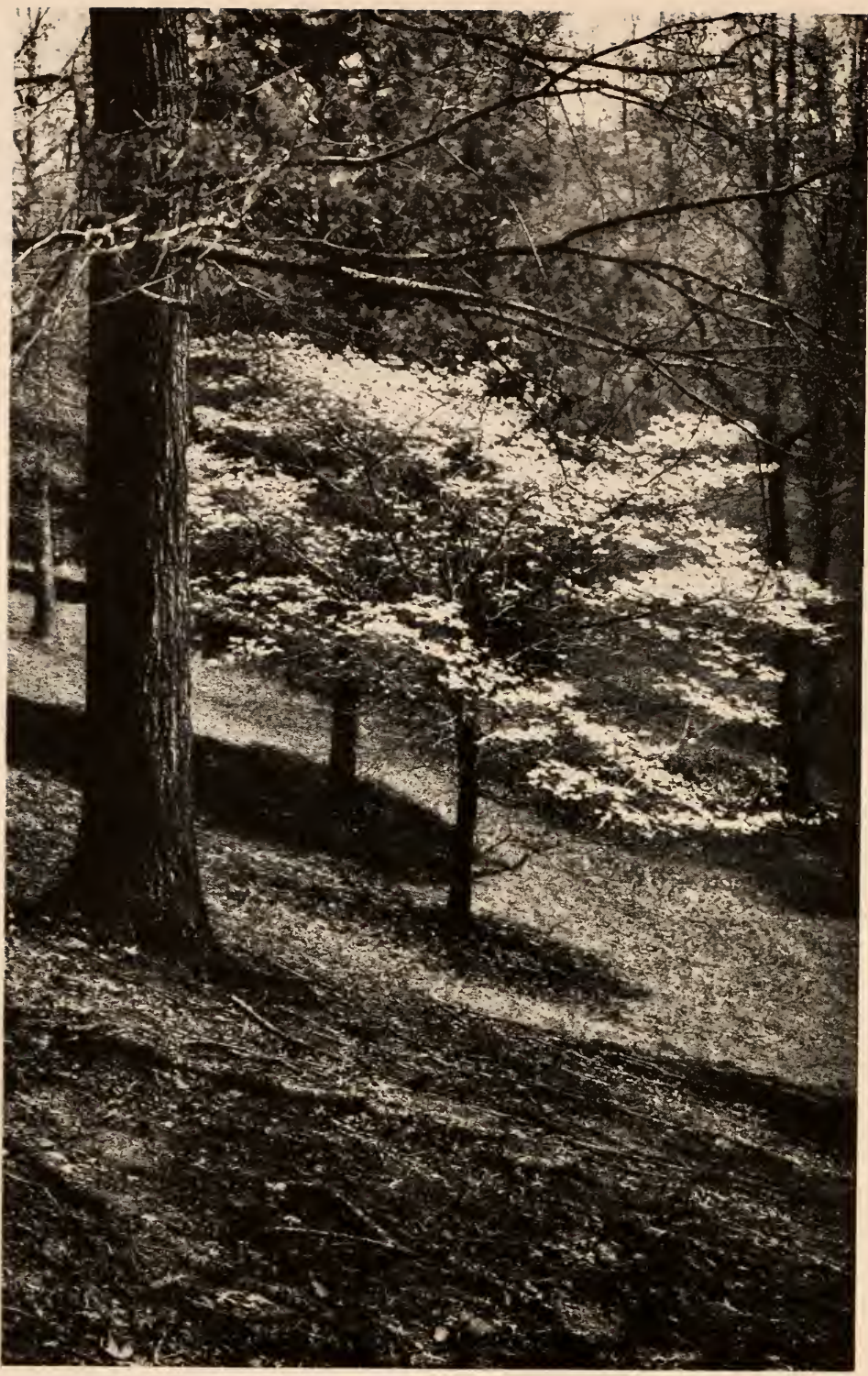




\section{FOREST FANCIES}

BY

LUCY CHARLTON KELLERHOUSE

\section{ILLUSTRATED}

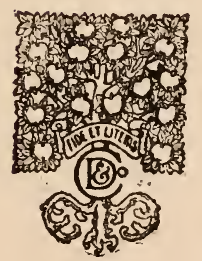

NEW YORK

DUFFIELD AND COMPANY

I9I 7 
Copyright, 1917, by

LUCY C. KELLERHOUSE

$238 \%$ 


\section{LOROL:}

I inscribe to you these little stories told me by the trees. 
"If one wishes to study the life-not the mere structure-of an apple-tree in bloom, he must surrender himself at the start to the bloom and fragrance; for these are not mere external phases of the growth of the tree-they are most delicate and characteristic disclosures of its life."

Hamilton Wright Mabie. 


\section{BEFORE WE ENTER THE FOREST}

Come, let us enter the Forest, leaving the world behind. Here the trees will tell us of themselves and their work-what they do for you and for me. The Forest speaks to all who will listen, though every one translates its message in a different way. Four men once entered the forest: a scientist, a pastor, a teacher, and a poet. The scientist brought away a treatise; the pastor, a text; the teacher, a lesson; and the poet, a song. I, too, found my way into the Forest; and all that $I$ heard there I put into words, which took the form of a story.

One day I showed my story to a forester, who loves the wildwoods of our land; and he paused in his busy work to read what the trees had told to me. As these stories are not really mine, but only my interpretation of what the 


\section{BEFORE WE ENTER THE FOREST}

Forest will reveal to every $y_{1}$ listener, I will repeat what that forester said:

"I have just finished reading your admirable articles. Will you let me say I have read them with the keenest pleasure. Their daintiness, kindliness, originality, and charming fancy have made me enjoy them very much indeed. I sincerely hope they may be published and widely circulated, for they are far too good to be suppressed. They will be read with profit and delight.

Gifford Pinchot."

And now, to the Forest Service for its pictures of the woods, and to all who have helped show me the way, let me gladly, offer thanks, before we enter the Forest. 


\section{FOREST STORIES}

Quercus............................................... ${ }^{25}$

A Strvan Easter................. 53

The Linden-Tree of Jonsboda.......... 75

Forest Leaves.................... 95

The Merry Greenwood............... 117

The Fruit of the Christmas Tree. . . . . . 143 



\section{FOREST PICTURES}

The Surplice of Spring........... Frontispiece Facing
Page

Quercus Offered Himself Up to the Teeth OF THE SAW................. 10

And So He Went from Tree to Tree...... 26 The Scattered Maples on the Hillside.... 30 Uncle Isaac, Long and Lean, Came to Help in the Sugar Bush.............. 40 Little Bells with Ruby Clappers........ 54 The White Poplar Was Already Awake.. 58 The Cottonwood..................... 60

The Boxelder Was Green.............. 62 Easter Chimes.................... 66 The White Birch and the Beech Tree... 68 The Pomp and Glory of Spring......... 72 The Sweetness of Its Summer Bloom..... 82 Far Beyond the Valiey.............. 98 "Come, Rest Under My Branches"..... 102 Drivers Guided Them into the Current.. 108 In A Quiet Harbor.................. 110 Once Upon a Time There Was a Forest.... 118 The Conquest of the Forest............ 122 The Roots that Bound the Earth, the Boughs that Shaded the Moist Earth, Were Gone.................... 126 "Full to the Brim Our Rivers Flowed".. 130 He Meted Out Land for Farm and for Forest......................... 136 A Littile Balsam-Fir Tree Grew in a Forest 144 Christmas in the Woods.............. 156 



\section{QUERCUS}





\section{QUERCUS}

Our virtue should not be a deed, or a work, but a growth-a growth like a tree's, always rising higher from its own inward strength and sap. -Phillips Brooks.

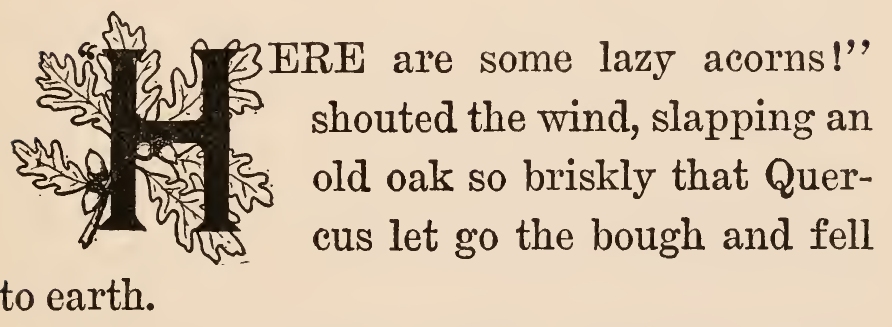

This was his first contact with the world. There he sat on the moss, like the cat on the mat in the primer; yet he did not long for greater prominence, for to be obscure is to be secure.

"Ah!" cried he, as something light and winged whirled by, "airy fairy, who are you?"

"I am little Pinus," answered the winged 3 
one, sinking to rest. "Dear me, I'm all out of breath, for I've waltzed across the valley!'”

"A long way from home for one so young," observed Quercus, cuddling down among the falling leaves. "Nothing doing, so I may as well go to sleep. Be sure to wake me when spring comes." And before he knew it, he was sleeping as soundly as Rip Van Winkle.

When Quercus awoke, he looked at himself in surprise, and just like Mr. Van Winkle when he discovered his long white beard, asked :

"What's this on me?"

It had broken right through his smooth coat -a tiny root. Quercus lifted his head and looked about, laughing so hard that he split his sides more and more; until his ragged coat fell off and he stood like the little prince in the fairy tale, straight and proud, with a green cap on his head and a feather that grew longer.

The little root busily burrowed through the leafy mold; yet until he had a good firm grip of the earth beneath, Quercus feared lest 
weakness overtake him and he die, like many of the tiny seedlings near, striving to be trees; but at last he got a firm grasp of the situation.

Then Quercus stretched with all his might, like a lazy, growing boy-stretched himself higher, and put on new raiment in keeping with his larger size. When he got tired of standing on one root, which was his taproot, he sent out root branches underground, and one day ran across someone in the dark.

"Helloa," he called, "who's there?"

"A pine tree," was the answer.

"Dear me, if it isn't little Pinus!" exclaimed Quercus. "So you, too, have gained ground. But this belongs to me."

"All I ask is standing room," Pinus replied.

"And if I can get a bare subsistence from the soil," said Quercus, "I shall be satisfied."

Quercus won his living not only from the soil, but from the air as well. His root-tips were covered with hairs, and at the end of each hair was a thirsty little mouth, drinking 
water flavored with various nutritious brands of minerals. Every leaf above was a green tongue calling to the roots below for water; and up it came, through the tiny cells; and when the leaves and green bark received it, they made a new mixture, like the busy little chemists that they were. The method that they followed had been handed down from generation to generation; so you see that the mixture must be good-good for oak and ivy, with a slight variation in the ingredients. Old trees never fail to recommend it to little trees; they say, "Look at me, see the benefit I have derived therefrom. I am a living advertisement of its nutritive qualities," adding that it is pleasant to the taste.

But here is the method itself: Out of the air is filtered the same kind of gas that makes bubbles in your soda-water. This gas the busy chemists split up, returning some of the oxygen to the air, but keeping all the carbon, or the part of wood which makes charcoal. Then they split up the water that the roots send up to them, and mix in the carbon to make some- 
thing else called starch, which, with the earthfood brought up from the soil, forms their staple article of diet.

Quercus followed the good old method, and when he had nicely compounded the mixture in his leaves, the sap carried it to every growing part, somewhat as hod-carriers take the brick and mortar to the proper parts of a growing building, and what was not needed at once was stored away for future use. So Quercus grew taller and stronger every day, summer after summer, for the chemists work only when they have light and warmth, and night and winter are times of idleness. When autumn came, his leaves ceased to be thirsty, and the cell ducts, like a soda fountain, awaited spring business. Then would come a brisk demand on the roots for water, and the new leaves and green bark would get busy.

Other young trees were eating and drinking and stretching and growing. It is said that one-half the world does not know how the other half lives, and little the proud, uplifted branches knew of the struggle going on under- 
ground. The branches soared while the roots delved and pushed against one another, like children kicking each other under the table, and every year some trees lost courage and foothold and gave up the fight, for to the strongest was the victory.

Still, the branches had their own troubles. 'Smarter trees overshadowed slower ones, and sometimes it was too dark in the forest for little trees to see their way up, and they, too, stumbled and fell in the struggle. Even Quercus could not well see how to mix his food, and grew weak in the heavy shade. Must he also give up at last, as he had seen so many donever rise and interlace his branches in the canopy of crowns far above, and receive the blessing of the sunlight on his head? Must he wither and die and fall, leaving no record of strength and courage and achievement? $\mathrm{He}$ tried to take his food and grow, faltered, saw his fate before him-to enrich the mold for those stronger in the struggle. It was this, 'or a century of life-perhaps centuries of kingly power. 
A storm swept over the forest, and veterans brought destruction in their fall. Yet out of calamity came blessing. Quercus bowed his head, but lifted it to light and victory.

The sun looked through the broken clouds and broken ranks of trees, upon Quercus and Pinus, and asked what were they thinking about? Why weren't they busy? They blinked in the flood of light, hesitated, saw little strangers at their feet surrender and fall before the sudden onslaught of day; then they took heart and began anew.

Oh, how Quercus stretched himself! There was that glorious open space above, and he far below, like one in the depth of a valley. Athwart this valley was sapphire sky, atilt for the golden draught of sunlight to pour in. But what was outside this valley, beyond the crowns of the veterans? Quercus longed to know. He tried to stand on tiptoe; he stretched his neck, yet could not see. Others were trying to see, trying to reach that space of blue. He strove to get there first, for the laggards would miss the prize of sunlight on 
their heads. Some did not care-were content with the shadow, but Quercus was proud and would not brook the shade.

Sometimes he bent before the wind, sometimes he bowed beneath the snow, yet steadily Quercus grew. He had roots firm in the ground, a fine, straight stem, and a crown of leafy branches. He dressed like the other young oaks in the forest. If he wore branches lower than forest fashion demanded, they were overshadowed and withered away. The fashion of the open country was to wear branches low, but Quercus was a social tree and must follow the fashion of the forest; so, not liking ridicule, he kept his stem as smooth and trim as he could and tried not to adopt the ways of country trees that grow in the open.

Yet in spite of all this youthful vanity, Quercus had a good, sound heart, though he was a little sappy.

The heartwood of Quercus stood in the relation of a skeleton to him. It was hard and strong, with closed-up cells, for the sap arose through the softer tissue of the newer wood, 


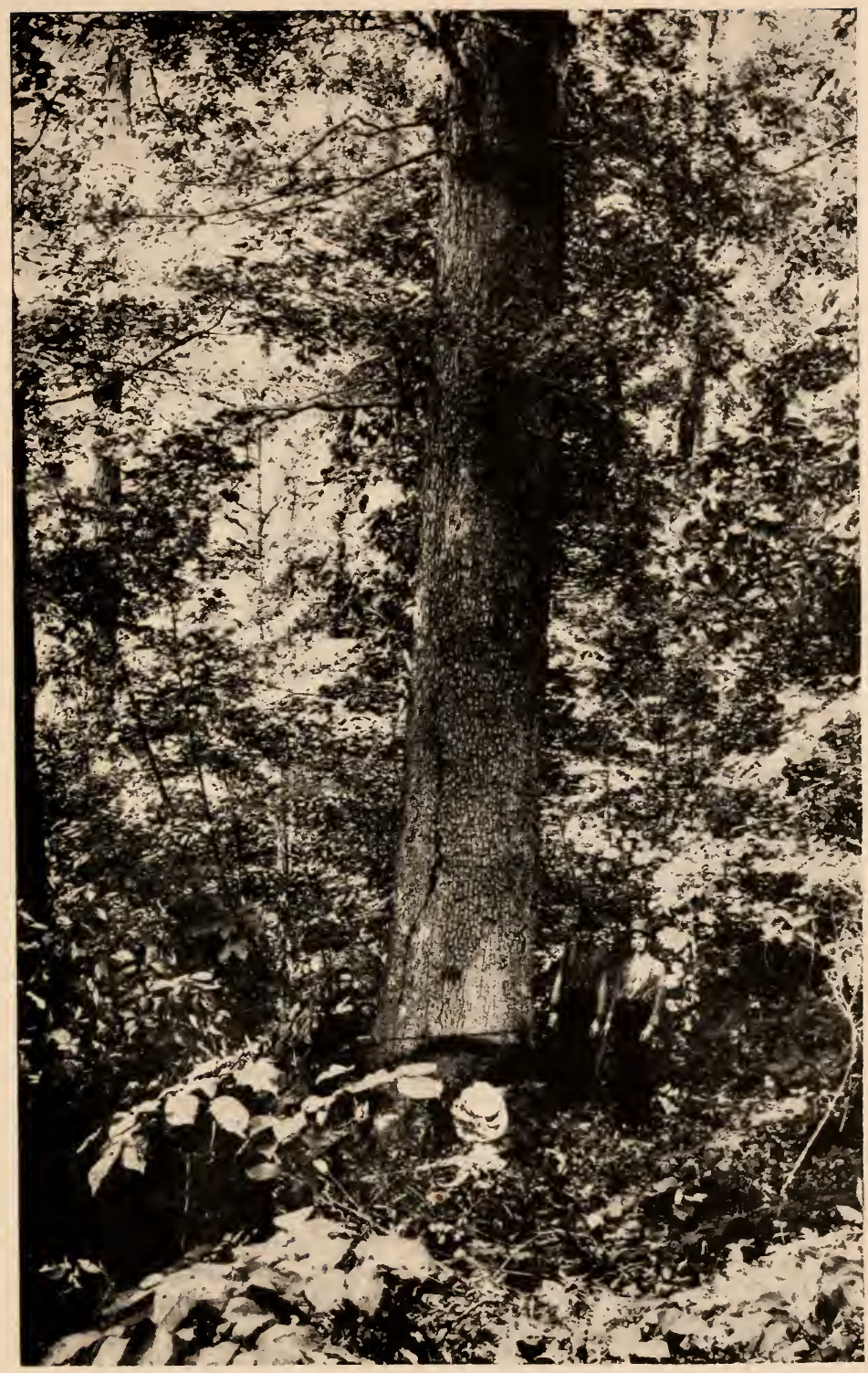

QUERCUS OFFERED HIMSELF UP TO THE TEETH OF THE SAW 
called sapwood. Each spring's growth formed a new ring of wood around the old, with thin walls to the cells through which the water couid hurry up to the laboratory in the leaves. In the summer the cells were stouter walled and smaller mouthed, making a finer honeycomb, or as you would crochet a pattern closer-if you are a girl-only, of course, these cells were much smaller than any stitch ever taken with a crochet needle. Through these rings ran the silvery pith rays, made up of storage cells.

As Quercus grew stouter, the new rings of wood became narrower. Between the last ring of wood and the bark, a thin layer of cambium covered him from top to toe, only this garment did not shrink, as your union suit is apt to do; it constantly grew, forming new wood on the inside and new bark on the outside. And thus he grew very stout, and every year had to let out his coat, which began to look quite seamy.

So Quercus became, in the course of time, a fine, large tree. He had conquered many enemies, not least among which were insects, 
small, but powerful. Fungus was ready to attack, the mistletoe had sought to overcome. Yet these had taught him the strength of little things, the power of the weak when persistence takes the place of might. It was the yearly growth of tender buds and tiny cells which had given him his powerful frame and made him monarch of the forest.

Quercus had conquered the years-a century of them; and not insects, nor fungus, nor mistletoe-not sun, nor shade, nor wind, nor snow-had marred his strength. Yet the time came when, like Shadrach, Meshach, and Abednego, he must pass through the fiery furnace.

By day Quercus had rested in the silence of the forest; by night he had listened to that Voice which is like the sound of a mighty ocean in a mammoth shell, when Life breathes upon the forest and it becomes alive with myriad small beings, awake and musical. $\mathrm{He}$ had listened to the wind passing over the windharp of trees, with the soft touch of the zephyr or the reckless crash of the storm, when boughs 
broke like snapping strings. But one day there came a sound which was not the rush of the restless wind, though the wind was awake, lashing the fiery steed that he drove till its red mane streamed far over the forest and the dust that marked its track clouded the sky as smoke.

The wind drove the fire close upon Quercus, who felt the thickness of his armor of bark and yet was afraid-not for himself but for the child-trees, for the nestling birds, for the bright-eyed squirrels. He looked at Pinus, slim and straight and tall and proud, but Pinus said:

"My armor is thin; to you at last will be the victory!"

The wind caught the words. "The fight shall be more fair," said he, tearing away the wings of flame, and the maimed steed crept along the ground, past Quercus, past Pinus, stopped at the stream that flowed through the forest, and quenched its burning thirst. But about the feet of Quercus the red lips had licked up the tender seedlings, leaving the 
ground black and dry; and the red mane had rubbed against Pinus and left a scar.

As in the soul of Man, where the weak spot is, there evil enters, so disease came to Pinus through his wound. He weakened with the years, and failed to claim his birthright of two centuries or more.

Once, years past, men had entered the forest with sharp saws and cut down and carried off some of the largest trees. Quercus often wondered whither these trees had gone, and one day asked the wind.

"They went to the mill," replied the wind, "to be sliced into boards and shipped into towns."

"And then?"

"The boards were made into things useful to Man; for Man wants a great many things, without which he thinks he cannot be comfortable or happy."

"What does Man make out of our wood?" asked Quercus.

"Ships that float on the water, bridges so that he can walk over the water, carriages in 
which to ride, houses in which to live, beds and chairs to make him comfortable, fences so that he can own a piece of earth and keep his neighbor off."

Almost every day, as the wind went hurrying by from over plains and cities and seas, the trees asked him questions. Strollers in the wood, listening, said, "Hear the wind talking through the branches."

Only they did not really believe that the wind was talking, though all the while he was telling the trees what use Man made of their wood.

"I should like to be a house," said one, "a beautiful, sweet home sheltering a family of little children, even as now I shelter birds and squirrels."

"And I," said another tree, "should like to be the table around which they gathered morning, noon, and night. Years afterward they would remember me, around whom they had so often met."

"And I would be the chair in which the grandfather sat," said a third-“a good, gray 
grandfather, who had worked strenuously, and whose last years I would make comfortable; and when he was gone, they would look at me and love me and leave me in the chosen place."

"I should like to be a bridge," said a fourth, "and know the ceaseless tramp, tramp of passing feet. Many feet would touch me, and by their tread I could tell why they touched me as they did-whether joy or sorrow or business or idle fancy took them over my prostrate form. As the feet touched me, I should be thinking, thinking, all day long, and even at night there would be stories to tell."

"I would be a church steeple, ever pointing upward, even as here I have striven to come closer to the mystery of the sky," said Pinus with his failing breath, well knowing that upon this earth his work was forever done.

"I would be the mast of a ship that rides triumphant over the deep sea." said the son of Pinus.

"And I," said a young oak, "would be the 
ties over which those iron monsters fly, fast as the wind, bearing their freight of human lives."

"I would be a tall pole," said another, "with wires where now my branches are, and Man's thoughts would fly over them faster than squirrels, faster than the flight of birds."

"Nay, I would be none of those things," said a hickory. "I would know the touch of the keen axe until I was hewn into a thousand pieces, and these pieces should be placed in the grate about which the family gathered on a winter night. Then the red flames would clasp me and crown me, even as the green leaves now bind my brow, and the fire would leap through my veins, even as the sweet sap now flows through them, until at last that which had been given me by the earth, would return to the earth as ashes, and that which had been given me by the air, would be freed from the bondage of my being and return to the spirit of the air."

"And what would you be?" asked the wind, caressing the giant frame of Quercus. 
"I would be the cradle of babyhood," replied the king of the forest, while the laughter of the trees ran like squirrels over the branches. Unheeding, he continued, "And as I rocked the child, I would whisper tales of the forest, till he smiled at my fancies and slept his innocent sleep. I would tell him the stories of acorns and ivy and birds. What the wind has told me, I would tell him, till his fancies were as flowers and the sunbeams of happy thoughts touched him with their radiance. And all the while I would be giving him the strength which is the strength of a great tree, the patience which is found in the growth of a century, the endurance which comes from a struggle for life from infancy.

"What I have attained, he should attain, my strength should be his strength; and he at last would be crowned with victory in the struggle of life, even as I am crowned with branches and leaves. And while he stood firm on the foundation of world-wisdom, upon his head would rest the eternal sunlight of a Higher Truth-the consciousness of Life Divine. 
Night after night I would hold him in my arms and teach him these things."

They were silent as the monarch paused.

"May your wishes come true, dear children of the forest!" whispered the wind, touching them lightly at parting.

Quercus thoughtfully sheltered the birds, gave food to the squirrels, offered a staff to the struggling ivy, and a home to myriad small creatures.

"Should Man never need me, is this all there is for me to do?" he asked the wind one day. "Look high over the other trees," replied the wind; "see the streams winding through the land, with water for stock and city, mill and ship. How finely the green hills slope to the valley, fruitful and populous! You and your brothers and sisters are the bulwark of safety about this smiling land. Your roots bind the soil upon the hillside, and under the forest floor is a hidden well of rain, from which the springs forever fill their overflowing vessels. So the good streams bless you for life, and Man blesses you for his prosperity." 
Quercus saw the browsing cattle, the fields of shining grain, the bending orchard boughs, and said, "I would remain here to the end of my days."

"Look," said the wind, inclining the oak's head.

And Quercus saw the young trees struggling for life.

"In time you must die," said the wind. "If then your children are dead, who will take your place in the forest?"

Quercus was silent.

The following day men came with sharp saws, as strong as the teeth of the storm. Quercus, looking down at Alba, his offspring, beginning to falter in the mighty and everlasting struggle for existence, said, "A life for a life," " and offered himself up to the teeth of the saw.

And when he, the monarch, had fallen, and they had stripped the crown from his head and borne him away, the forest became silent; the birds gazed questioningly at the vacant throne, the squirrels glanced timorously at the 


\section{QUERCUS}

great rent in the leafy forest roof; while the wind, passing his hand over the harp of the trees, and seeking in vain the strong, deep note that had rung so long in the forest harmony, swept the strings tenderly, and was still. 
THE SUGAR MOON 



\section{THE SUGAR MOON}

"T $\mathrm{T}$ is time for the maples to wake up," said Nokomis, the earth-mother.

They were still drowsy atop, though down in the ground the sleepless rootlets, thinking the snow all gone, were wide awake and very thirsty. So the trees drew up soil-water through their cells, and the sugar stored away last year in the form of starch, now sweetened the flowing sap ready for the first spring food of the awakening buds.

"The sap stirs," said Farmer Brier, "and it's time to sugar off."

Many, many years ago-so the Indians tell -Nokomis, the earth-mother, made maple sugar. One day she cut small holes in the trees, put a little piece of wood into each hole, and placed a vessel under it. Then her grandson, the hero Manabush, looking into the ves- 
sels, found them suddenly half-full of thick sirup. He put his finger into the sirup, then popped it into his mouth, and found it sweet.

"My grandmother," he said, "this is all very good, yet it will not do to have the trees give sirup in this way. The people will not have any work to do if they make sugar so easily; they must cut wood and boil the sirup several nights, to keep them busy, that they may not form bad habits. I will change all this."

Then Manabush climbed to the very top of a maple tree and threw water all over it like rain, to dissolve the sugar and let it flow from the tree in the form of sap.

So Farmer Brier had Manabush to thank when he cut much wood in his grove, ready, to sugar off.

He now brought an auger and bored a hole in a maple tree, and when he had driven in a sumach spout and hung a pail for the dripping sap, he bored a hole on the other side of the tree, drove in another spout, and hung another pail. So he went from tree to tree. 


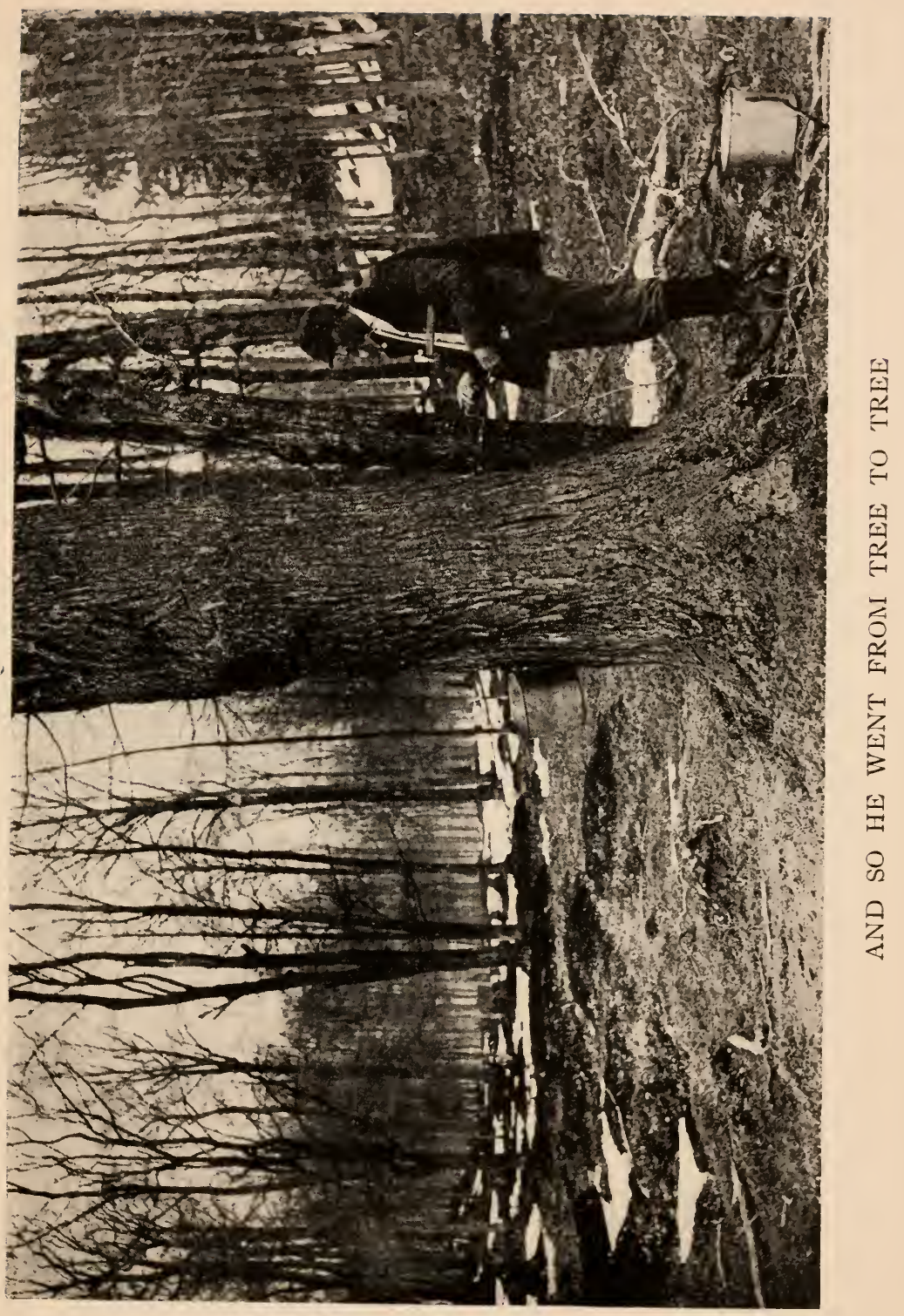


Two children followed their father into the wood. "Sister, the sap is running!" cried the boy.

"Brother, I cannot see," sighed the little girl, tiptoeing.

As Brother lifted her to let her look into the pail, he heard a sound-not the wind, or the welcoming frogs, or the returning robinsno, it breathed from the very heart of the tree, a sigh, as when one awakens. A tremor passed over the branches, which was not from the south wind's caress, and a sweet spirit in the maple tree awoke to life.

"Let us follow Father," said the boy, "and see him tap the trees."

Then the spirit in the maple tree smiled and tried to reach out to him; but, alas! like the sunshine, she had no hands, so she watched the children follow their father through the wood, longing to be a child with them and pondering how her wish might be realized.

"I will ask Old Nokomis, the earth-mother," she said to herself that night.

The snow was falling, clothing the trees once 


\section{FOREST FANCIES}

more in their winter white, and Old Nokomis, the earth-mother, wore ermine on her blanket as her moccasins fell softly on the carpet of eiderdown, leaving no mark-though the rabbits left their fanlike footprints and the squirrels their tiny tracks.

"Nokomis," cried a voice from the maple tree, "when in mid-March the father comes tapping the trees, the children follow. Give me hands to touch and feet to run, eyes to see and lips to laugh, and loose me from the bonds of the maple tree-for the children are sweet, sweeter than the maple sap!"

Old Nokomis, gazing at the tree's shaggy bark, long past the smoothness of youth, replied, "Daughter, you are a child in spirit, though your maple tree has grown old. Yet, old as is your maple tree, only I remember the days before the Pale Face brought his snowwhite sugar and his golden honeybee; only I remember how the Red Man slanted his cut in the maple's side, gathered the sweet water in vessels of bark or clay, and dropped in the heated stones. The tribes had a festival or 
a Maple Dance, for the maple sweet was their April food and they welcomed the Sugar Moon.

"Then by-and-by fair-faced children came begging for the sweet taste as their fathers tapped the trees in the old Indian way, caught the sap in wooden troughs, and boiled it over a fire in metal pots."

"But tell me, I pray, more about the children."

"Daughter, you are impatient," said Old Nokomis, the earth-mother. "You long to steal forth with the flowing sap and be a child at the sugar-making."

"Yes, that is my wish. And I would remain as other children, and live in their home and grow and work and play with them and be always one in their midst."

"So shall it be," said Nokomis, "unless the spell be broken."

"What spell must not be broken?"

"Love, like sunlight, will draw you forth; but discord, like the frost, will drive you back. Will you go?" 
"I will go."

"When I call, you must come; for only while the sweet water freely flows will you have eyes and ears, to look and listen, and hands and feet, to touch and run as children do. But when the buds awake and the leaves unfold, I will call no more."

Then Old Nokomis and the night shadows and the veil of snow were gone. The pale flower of dawn bloomed in the sky, and all was white and pure like the heart of a little child.

When Farmer Brier drove with his sledge to the wood, he had a barrel for the sap from the scattered maples on the hillside. "What a good run of sap," thought he, emptying a pail into the carrying-bucket; "I guess there's enough to boil."

He shoveled the snow from the two big back logs, over which he hung a caldron and a kettle, each balanced on the end of a long pole set across a post. The heavy pole was weighted with stones at the other end, to turn the caldron on or off the fire. Then he tore 


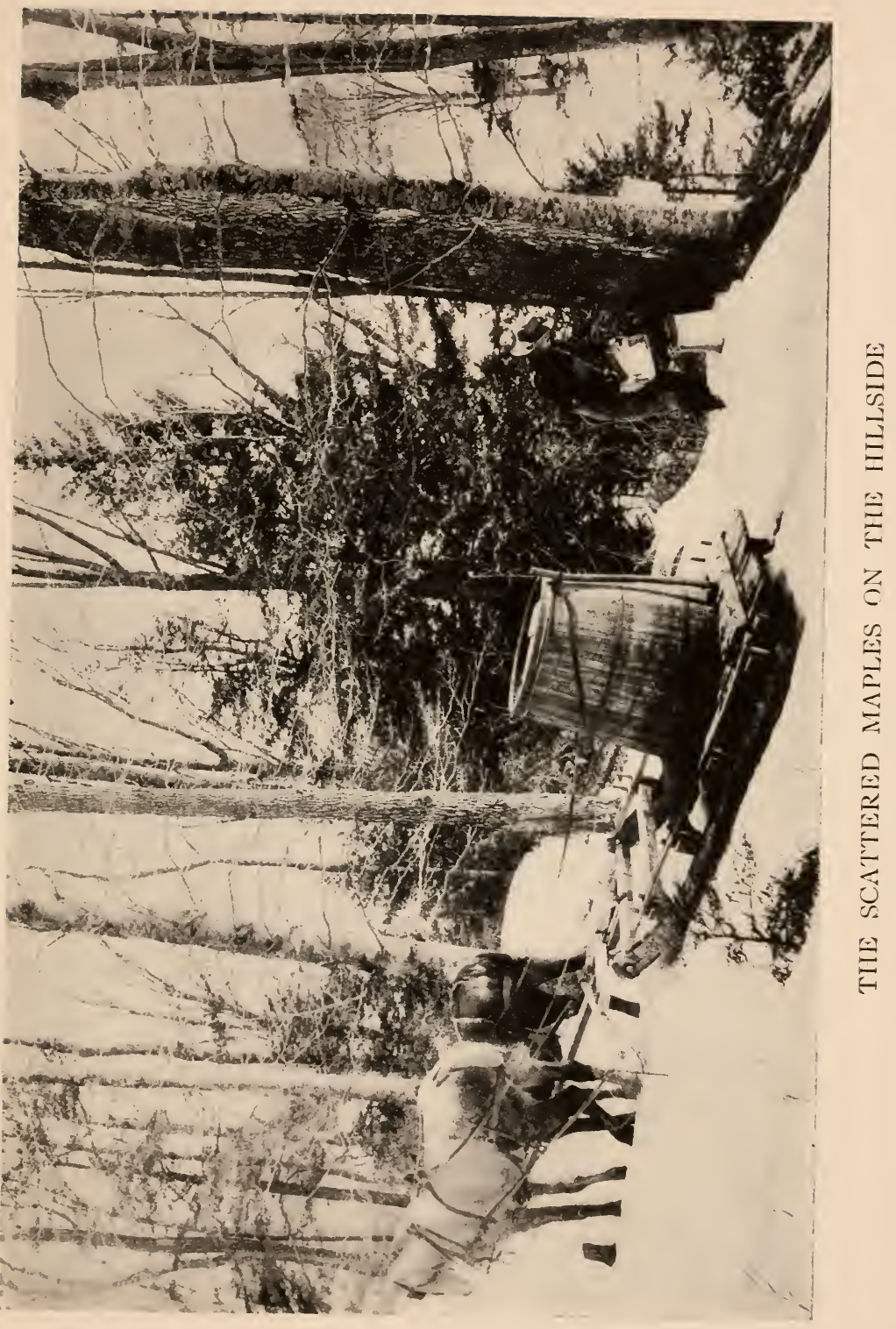



bark from a birch tree and struck a match.

Ready to gather the sap of near-by trees, the two children came racing through the snow.

"Lemme taste the sugar water," begged the little girl, all eager.

So the boy lifted a shining pail to her rosy lips-when a little maiden slipped from the tree in a most surprising way, like a sunbeam sliding to the ground and taking form. He started, and almost dropped the pail.

"Helloa!" he cried. "Who are you, anyway?"

"Nani," replied the stranger.

"Nani what?" he asked.

"Only Nani," she answered wonderingly.

"How funny," he said; "why, our names are Dick and Dotty May Brier."

"Then I am Nani Niset-sugar maple girl," she laughed, and so the three made friends.

" "Tis a neighbor-child," thought Farmer Brier, as Nani joined the children at their task.

As the sap boiled, Farmer Brier dipped it from the caldron into the kettle, and threw 
in cold milk to keep it from bubbling over. Dick drove Dotty May home on the sledge, but Nani remained in the sugar bush to help dip the thin sirup into a barrel. Suddenly she paused; the sun had set, and there was frost in the air.

"I hear the earth-mother calling," said she, "and I must go."

"That's a good girl, mind your ma," replied Farmer Brier, looking around.

But Nani was nowhere to be seen.

When Dick returned, he questioned his father about her.

"She went mighty sudden," said Farmer Brier, simply, "but I guess it's all right."

The next day, Uncle Isaac, long and lean, came to help in the sugar bush.

"Where do you live at, anyhow?" he asked as Nani joined them in the maple grove.

"I live in the sugar bush!" laughed she.

"Hev your folks made maple sugar long?" he questioned her further.

"Nokomis, the earth-mother, made maple sugar before the White Man came." 


\section{THE SUGAR MOON}

"She must be a very old lady," observed Uncle Isaac.

"Yes, she is old" - and Nani laughed again - "she is old, as old as the earth!"

"That's six thousand years," said Uncle Isaac, who was very orthodox. "She can't be that old. Even Methusely was only nine hundred years old. Do you know the Ten Commandments?"

"I know but one commandment," answered Nani.

"What's that g"

"Love," she replied, and ran to bring more wood for the fire.

At sunset Nani slipped away among the shadows, and none saw her go.

She did not return on the morrow. It was too cold for the sap to run, and Farmer Brier washed the pots and pails and waited for spring weather.

Dotty May had followed her father into the sugar bush, but was not to be seen when he started for home. There was no reply to his loud "Helloa!" so, thinking she had gone 
home, he went whistling through the wood.

Dotty May had come to tine maple grove, not for the sake of the sugar water, but to seek her playmate Nani. She went far into the wood in her quest, but no Nani answered her call, and now night shades were falling and the frost was pinching her little nose. She sat down on a stump and began to cry.

"The little one cries for me," thought Nani; "could love give me a form, I would go to her." And her feet bore her swiftly to Dotty May.

"Nani, my Nani!" cried Dotty May.

"I have come, dear, for just a little while," said Nani. "Come, take my hand, and I will lead you home."

Smothering her sobs, Dotty May put her trusting hand into Nani's and trudged beside her through the shadowy woods.

"Hurry, little one," urged Nani, as they. neared the maple grove.

They were now on the hillside, in sight of home.

"Good-bye, Dotty May," she said, loosening 
the clinging hand. "The arth-mother is calling me, so run home as fast as you can."

And before Dotty May could answer, Nani was gone-but where?

Sunny days followed, with frosty nights, so the days were busy ones for the workers in the sugar bush. Every morning Nani was there to lend a willing hand, but every night she slipped away and none knew where she went-it was like the passing of the sunbeams when the sun calls, and they obey his summons promptly like good children. And so Nani came and went with the sunbeams and seemed one with them.

One morning Aunt Miranda came to help boil down the sirup. Aunt Miranda looked as if she had been cut out of cardboard with a pair of sharp scissors.

"So this is the children's friend," she said, looking through her spectacles at Nani. "What is your name, did you say?"

"Nani," was the reply.

"Well, Nanny," said Aunt Miranda, "I guess you must hev been raised in the sugar 
bush, you air so handy at the siruping-down. I like useful children. Has your ma got many like you?"

"So many," cried Nani, "that she is going to let me come and stay with you!"

And she laughed as she ran to gather more sap, for the maples gave her plentifully of their store. Aunt Miranda's spectacles were very clear, and she saw that the trees responded to Nani's touch as if Nani were the very sunshine.

"She certainly is a likely child," she said briskly to Uncle Isaac and Farmer Brier, "and it would really pay to give her a home. Her folks most likely want to bind her out."

The thin sirup that had been saved from time to time was now put over the fire. When it was warm, Aunt Miranda stirred in beaten eggs to clarify it, and before it boiled, Uncle Isaac skimmed off the dark scum that rose to the surface, leaving the clear, honey-colored sirup to boil and thicken until ready to strain into the bright new cans. 
Toward evening Dick and Dotty May went aiter the cows, and Uncle Isaac followed to do the milking.

"Nanny, do you believe your ma would mind if you come home with me?" asked Aunt Miranda. "Couldn't you run home and ask her?"

The evening had turned warm; so Nani answered, "I may stay with you when the night is so mild that the sap will run."

"Some folks don't approve of their children staying with a neighbor overnight," remarked Aunt Miranda, "but I gues your ma knows who the Briers air."

They had reached the opening of the woods, and on the hillside below nestled the white farmhouse. Unasked, Nani's hand sought Aunt Miranda's, and she skipped gaily along beside her.

But Aunt Miranda glanced sideways at her through her spectacles. "Don't waste your strength that way!" she said sharply. "There's lots to be done in this work-a-day world-dishwashing, dusting, and sich like- 
and one can't afford to prance jest for nothing!"

Nani snatched her hand away, her radiance quite fading as she cried, "O Aunt Miranda, I can't go with you-just yet! I'm afraid"

"Afraid of what?" demanded Aunt Miranda.

"Afraid, Aunt Miranda, that you might break the spell!" and Nani laughed gaily, flitting away through the darkening wood.

So rapidly was the sap dripping that Farmer Brier prepared to continue the boiling all night.

The light of the campfire played over the gray columns of the trees and awoke the restless shadows under them. It danced in a circle, like an elfin ring, and a little bright figure skipped in and out among the shadows, with the firelight for a partner. Yet Farmer Brier did not notice; in fact, he was so busy that he had no time for dreams or dancing shadows or firelight frisking with an elf, for he was a simple, practical man, and when the moon 
looked curiously down through the bare branches to see what he was about at midnight in the sugar bush, she found him intent upon his task.

But Farmer Brier grew very tired, so tired that sleepiness crept over him, a drowsiness not to be thrown off. And so the ladle moved slower and slower; he sank down on a log and leaned against a tree, yielding to the enchantment of moon and firelight and the music of the dripping sap.

Drip, drip fell the sap into the pails, with different notes, some loud, some low, some quick, some slow, some near, some far away. Higher danced the flames, as if to look farther into the dark mystery of the wood; sputter, sputter, came from the boiling caldron; but Farmer Brier slept.

And now the little dancing figure with the frelight for a partner, glided from among the shadows and stole softly up to Farmer Brier, taking the ladle from his tired hand.

The dawn awoke him. Dazed, he looked around. Yes, he had slept at his post. The 
fire had burned out, and an empty caldron hung over the ashes; but near by, in a puzzling row, stood shining cans of golden sirup. "Done from start to finish!" he exclaimed.

Farmer Brier could not account for this, yet did not deny what he could not explain. He simply accepted facts, and went home to his breakfast.

A rainy day came into the midst of the sirup-making, when only Farmer Brier and Uncle Isaac worked in the sugar bush, but in the afternoon they covered up caldron and kettle and left the grove to the beating rain.

Nani, hidden all the morning in a hollow tree, now strolled lonesomely through the maple grove. Sometimes she peeped through the trees on the edge of the wood at the snug farmhouse nestled under the hill, and byand-by she sat down on a sheltered log to watch Dick and Dotty May romping on the porch. She could see Farmer Brier and Uncle Isaac at work, and hear Aunt Miranda call to the hungry fowls. Another figure, too, she saw through the veil of rain, a comfortable, moth- 


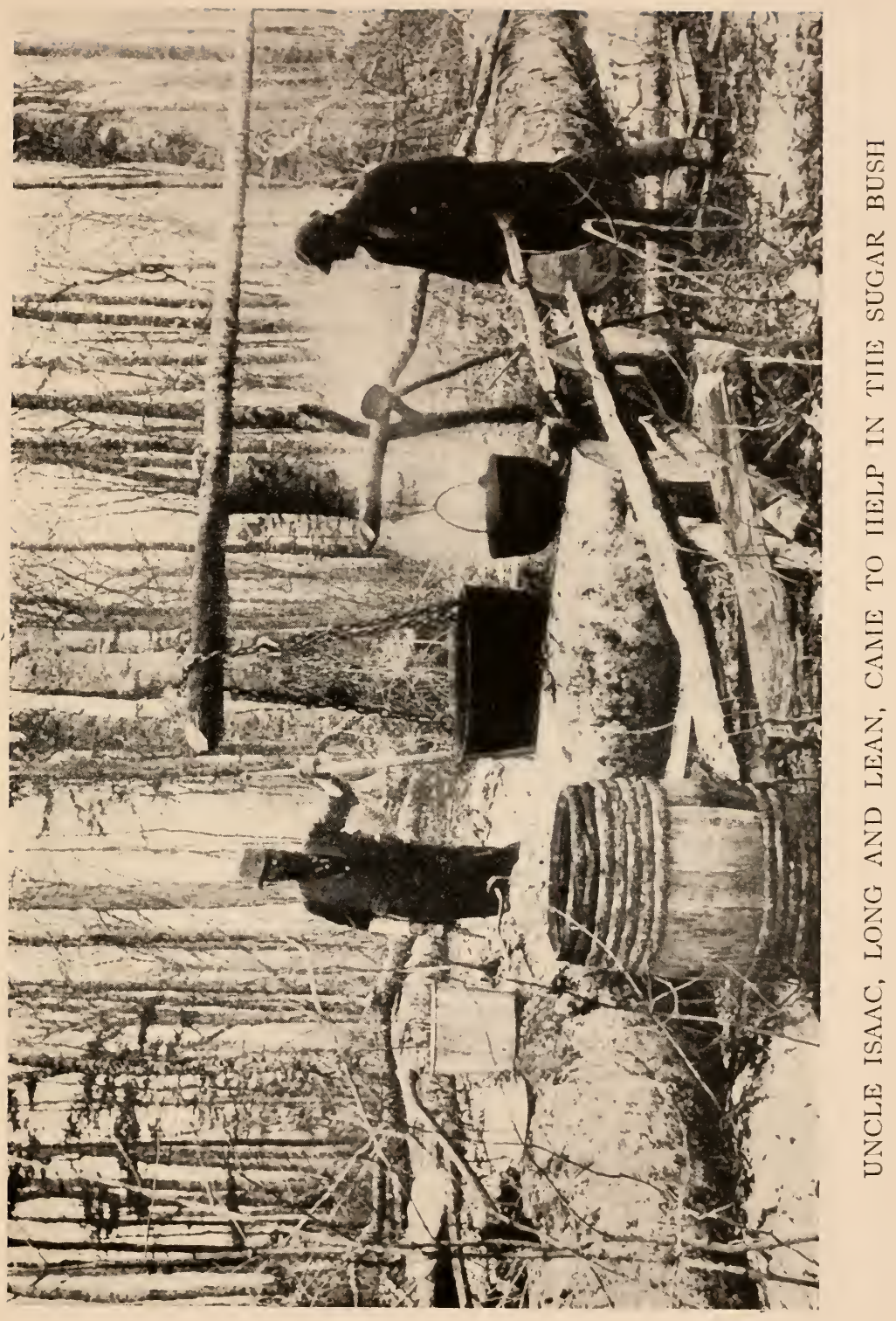



erly form moving in and out, bent on household tasks.

Evening drew near. Nani saw the mother, with cloak and umbrella and basket, go down the road; but she took a short cut home through the maple wood, and so came upon Nani sitting under the tree, watching for her return along the road.

"Dear child," she said, "why are you sitting out in the rain? Only little ducklings like so much wet." She sat down on the log and drew Nani close under the big umbrella.

"I do not mind the rain," replied Nani. "It makes the plants grow, and so perhaps it will be good for me."

"Are you far from home?" the mother asked.

"I live in the wood," answered Nani.

"Come, I will take you home under my umbrella," said Mrs. Brier.

Nani crept closer. "This is my home-right here."

The mother looked down at the strange child, of whom she had heard so much yet never seen 
before. "Tell me all about yourself, dear child. Where is your home? Have you brothers and sisters?"

"Oh, many, many!" Nani cried.

"Ah, yes," said Mrs. Brier thoughtfully, glancing at Nani's odd dress; "I see, you live in an institution."

Nani laughed merrily. "Yes, I am the inmate of an institution," she replied. "But when the maple buds awake, I may come and live with you, if___"

"If what, child?"

"If the charm be not broken," said Nani.

When the mother first put her arm, like a warm cloak, around the child, she felt as if she were holding a shadow-or a sunbeam, rather; but the longer they sat thus together, the firmer she seemed to hold Nani, into whose cheek a flush dawned and into whose clear eyes a look came which made her seem more real; and the mother-eyes, looking down into the bright face, half caught the mystery that she could not understand yet which her heart seemed to know. 
"It is well," said she. "There is a sunny room for you and Dotty May, and you, my child, will take the place of one who left me years ago-you will take her place and abide with me and be my own, to live not only in our home but in our hearts.

"And now," she added, "come home with me, out of the rain, for it is growing colder, and there will be a frost to-night."

"Ah, if there is a frost," sighed Nani, drawing back, "I may not go."

"Then good-bye, little one, for I must leave you." And the mother stooped and kissed her.

Nani sat down again upon the log, and looked long at the farmhouse as it melted into the evening shade. By-and-by a light sparkled from a window, then another; still Nani sat on the log, gazing wistfully at the happy. home. The rain turned to snow, yet she noticed not; but at Old Nokomis' call she started up, with a longing backward glance at the old farmhouse now gone to sleep under the hill. The sun, smiling through the bare branches, 
found an ermine carpet spread in the maple grove. He awoke the trees from their night napping, and soon the sap dripped gaily into the waiting pails.

To-day was the first sugaring-off, and the white carpet was soon tracked over by busy: feet. After the thin sirup had been boiled and stirred for hours, Farmer Brier looped a twig, dipped it quickly into the kettle, and blew through the film spread over the loop.

"It feathers," said he, "and the sugar is done."

The thick, amber liquid was now taken from the fire and poured into molds to granulate into golden bricks of sugar. There were two saucers in which to mold sugar cakes for Nani and Dotty May, but Dick had brought empty egg-shells to be filled.

"They are for next Christmas," he explained_- "one for each cousin in the city; but the big one is for Nani Niset."

"Christmas is a long ways off," drawled Uncle Isaac.

"Oh, but I love to think of it now, 'specially 
with snow on the ground," cried Dick. "Besides, if we thought of our friends only at Christmas time, how lonesome the rest of the year would be!"’

Dotty May, hovering over the nest of maple sugar eggs, picked up the large one, thinking of the game, "Heavy, heavy hangs over your head!" Just one little nibble, then another-

"How could you, Dotty May!' cried Dick, stamping his foot in the snow.

His eyes flashed, his cheeks were brighter than the flames.

"She is so little," Nani pleaded, her arms around the small offender; "she did not mean to make you angry, Dick."

Then he turned upon Nani, and his words rushed out like angry bees. What he said, he did not know, nor could he ever quite recall; but he saw her protecting arms release their hold, she drooped and faded like a flower that dies.

"Oh, where is Nani!" wailed Dotty May.

But only a withered leaf whirled by. 
Uncle Isaac, too, saw Nani vanish, yet he would not believe his own eyes because he could not explain what he saw. And when Dick sobbed out how Nani had disappeared, Aunt Miranda said decidedly:

"Reuben Brier, you let them children read too many fairy tales!"

But Nani was gone. It was useless to look behind trees or poke bare bushes. Yet to comfort Dick, his father said that he might go to the sugar camp a few miles away, to see if Nani could be there.

"She must be a sugar-maker's little lass," said Farmer Brier, "she was so handy at the sugaring-off."

So the next day Dick set out to visit the sugar camp near by; and if he had not been so intent upon finding Nani, he would have noticed how here the sap dripped through metal spouts into covered pails. He entered the shelter-building, in which the sap, flowing through a pipe from the storage tank, was boiled over a firebox in a partitioned pan. 
"Have you seen a little girl by the name of Nani here?" he asked of the man who was tending the sirup, so like in color to Nani's eyes and hair.

"There was a little gal here yesterday-a dark, sulky child," replied the man.

"That wasn't Nani, then," said Dick, "for Nani was sunny and looked like pretty maple sugar."

He would have continued his search to the big sugar-house still farther on, but vaguely realized that he would never find Nani among modern evaporators-no, he must look elsewhere. And so he returned alone.

The Sugar Moon was waning, and the darkening sap loosing its sweetness and flavor, so the holes were plugged with green wood, and the maple grove given over to the buds and the birds.

It seemed very lonesome to Dick and Dotty May as they trudged through it one day, bound to find Nani if Nani were to be found. Leaving familiar haunts, they wandered far through the forest, and finally came to a wig- 
wam, by the door of which sat a very old Indian woman.

"Can you tell me," inquired Dick, "where a little girl named Nani lives? We have come very far to find her."

The old Indian woman smiled.

"I was angry," he added frankly, "and she went away."

"Yes, I know," replied the Indian woman.

"Will she never come back?" he asked. "I did wrong, but want to make it right. Tell me where I can find her."

The old woman's face, like unto creased copper, softened at his words. Dotty May had ceased her crying, and was pulling at the Indian's blanket; for she was not afraid of her now, so fast did her face soften and the strange wrinkles disappear.

"There is but one way to find Nani," answered the Indian woman.

"Tell me," cried Dick-"no way is too hard!"

"The earth draws its life from the sun," she said, "but Nani drew her life from 
love. Your harsh words cut the golden cord. Yet you wish to undo what you have done."

"Yes," sighed Dick, with drooping head, "so tell me the way back."

" "The way back!" " she repeated. "People always fancy there is a way back when their error leads them into sorrow. But this time," she added gently, "there is a way straight ahead."

He looked up eagerly.

"Listen," said she: "when you have thought ten thousand kind thoughts, when you have said ten thousand kind words, when you have done ten thousand kind deeds, kindness will be a habit, and_- "

"Yes, tell me," he cried, "shall I find Nani then?"

"Yes, you will find Nani, brighter, more beautiful than before!" And her face shone radiant and tender as she bent upon the two children a smile like the return of spring.

Then the Indian woman and the wigwam were gone, and around them remained only the trees and underbrush and springing ferns. 
Dick took the hand of Dotty May and led her thoughtfully through the forest. They reached at last the maple grove, grown lovely now with bursting buds. Some trees, most impatient for May, wore a hint of tan-tinted leaves and a fringe of fairy bells. Dick gazed up at the shining treetops against the azure sky; the sunlight on them was like the shimmer of Nani's hair-no, it was more like Nani's smile. His face brightened; he did not really know, he could not say for sure, yet he was almost certain that Nani was with them in the maple wood. He smiled as he clasped tighter the dimpled hand of Dotty May: for did not love lead him nearer to his desire? And he knew that at the end of a sunbeam path, Nani would wait for him. 
A SYLVAN EASTER 



\section{A SYLVAN EASTER}

HALL flowers come first, or leaves? The red maple said flowers; the locust, leaves; while the beech suggested both.

The trees reviewed their wardrobes of velvet or varnished buds, where spring clothes had been packed away ever since last year, ready for the time when they wake from their winter sleep and have to get dressed in a hurry. None but a magician or Mother Nature could ever shake a flower-robe or leaffrock from such tiny bundles, though material is tucked away in cell cubby-holes to help out in the springtime dress.

While the trees were whispering together, three girls met out of doors.

"See the red buds beading the silver maple," said Portia, the gray-eyed girl. "Soon all the 
trees will awake at the sunrise of spring, and you will find flowers blooming where you had not thought there were flowers-high up on forest trees. We love sweet arbutus and violets so well that they seem all of spring; we forget that the alder is one of the first to hang out the flag of fair weather, and when we think the elm bursting into leaf, we do not know that she is adorned with little bells or seed with silver fringe. Many flower-banners will float in the bright air of Easter, as if the victorious trees heard the words, 'I am the Resurrection and the Life!" "

"Easter!" echoed Pearl. "I am so glad it is coming, for then I can wear my pink and white dress."

"I shall have a tan-colored suit," said Portia.

But Polly said nothing, looking down at her plain little frock.

"What does 'Easter' mean?" she asked presently, lifting her wistful eyes to Portia's face.

"Oh, 'Easter' means that it is time to put 


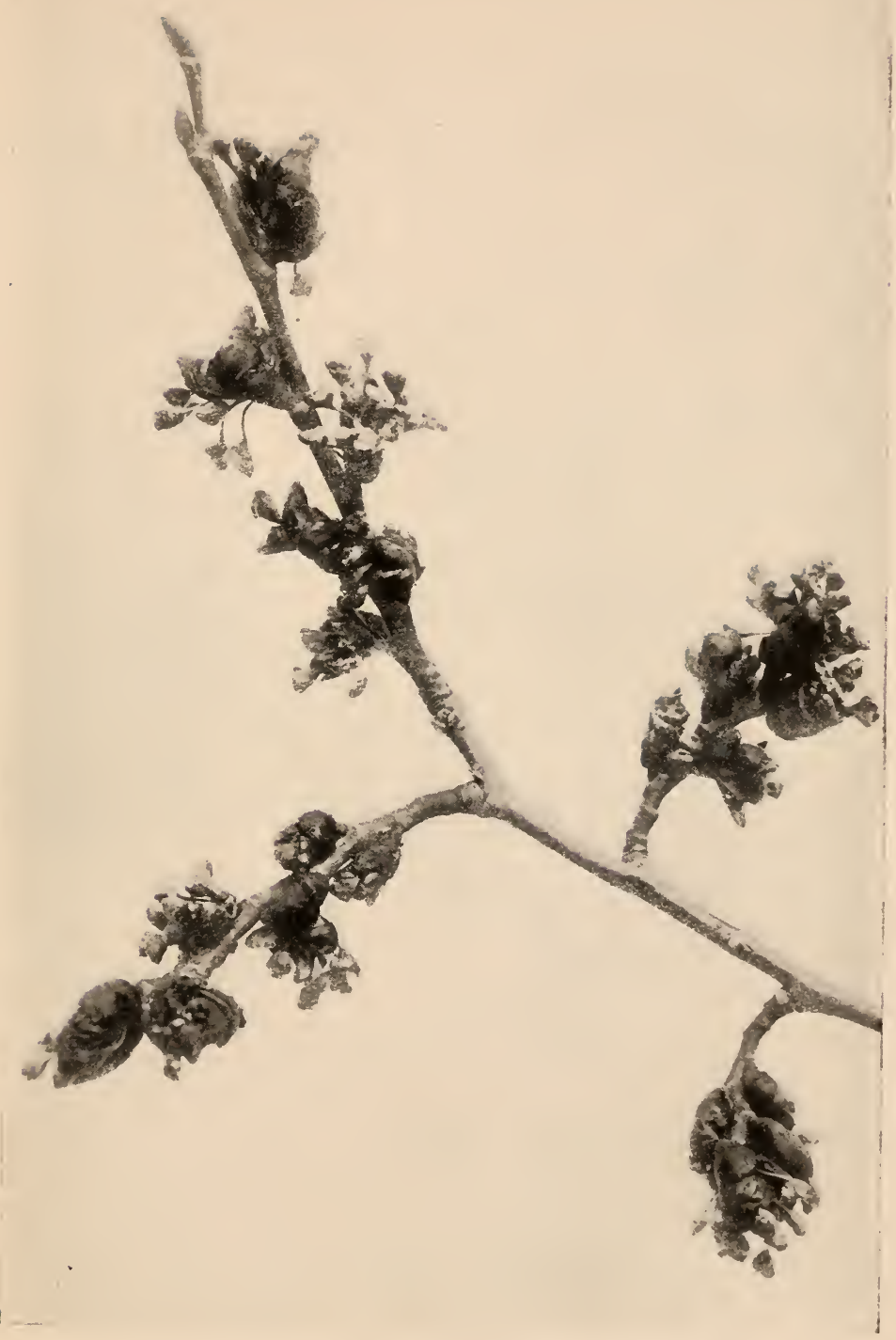

LITTLE BELLS WITH RUBY CLAPPERS 

off old winter clothes and wear something new and pretty!" cried Pearl, smoothing out her dainty skirt. "It comes in the spring, just the right time."

"When Easter comes," replied Portia, "I will tèll you its true meaning."

And then they parted, Portia and Pearl returning to the big house on the hill, while little Polly took the path through the wood and over the field to her humble home.

When the girls had left the lawn, the silver maple said, "Did you hear them say what they would wear on Easter? One said that it was the day to put on new spring clothes."

"Then we, too, must prepare for Easter," replied the little dogwood. "Our fashion of flowers is much prettier than theirs, and perhaps I shall look as fair as the girl with the apple-blossom face."

"That reminds me," said the beech, "that the orchard trees will put on their pink and white frocks before long. Who then will think to look at us?" 
"The robin will," answered the elm.

"And the bee," echoed the linden.

"Let us get ready for Easter," said the Norway maple, "and the robin will tell which one has done the best. Of course, we cannot compete with the orchard trees; they have their fashions, and we have ours."

"However," said the elm thoughtfully, "it is the one beautiful, sweet fashion of flowers."

"Flowers, flowers, flowers!" echoed every tree. "What shall I wear-flowers with stamens, flowers with pistils, or flowers with stamens and pistils both ?"

For stamens carry the pollen-powder atop, while pistils bear seed at their base, and sometimes one tree will wear only gold powder, the other pendants of seed.

Down by the stream the willows were budding.

"I intend to wear my furs on Easter," declared the pussy willow. "Easters are so often cold, and I have such pretty gray furs."

So he started spring fashions with bursting 
bud of red-brown scales, and soon was snug in silvery fur.

"You look very nice," commented the white birch, "though I fear you were in too much of a hurry; your furs are changing color, and will be a bit shabby by Easter."

For yellow stamens were pricking out through the down like so many bright pins, and when the bees had carried their gold-dust to the green pistils of the willow across the brook, the silky fur looked decidedly motheaten.

"Ah, well," sighed the pussy willow, "I have started things, anyway."

His neighbor, the alder, flung out her long jeweled tassels of russet and old-gold.

"I shall save my flowers for the golden days," said the tulip-tree.

"Not I," replied the alder, tipping her branches with tiny cones; and she fluttered her flag over the brook, scattering her jewels to the wind.

Meanwhile, the silver maple eagerly opened her garnet buds. Some branches she feathered 
with stamens, greenish-yellow, with tips of red; others were crimson with pistils.

" 'Tis airy attire," remarked the pussy willow, "for so early in the year."

"Oh, but I am a bit of the springtime!" How fair she looked through her veil of flowers. "We don't want winter fashions now, with comfy furs."

"So, so!" suddenly sang the snow, and before she knew it, she was muffled in white from top to root.

"Cheer up!" called the red maple gaily, flaming into crimson and coral flowers. "My heart is on fire with spring! Let us be glad, glad, glad!"

"Are we not glad!" And the elm, flushing with joy, burst into a million little bells with ruby clappers. A beautiful tune drifted down, like the sunrise anthem of the year. The laggard trees heard it, and began to stir.

But the white poplar was already awake. "For real comfort on a cool spring day," he said pompously, "look at me."

For while his mate was uncurling her green 


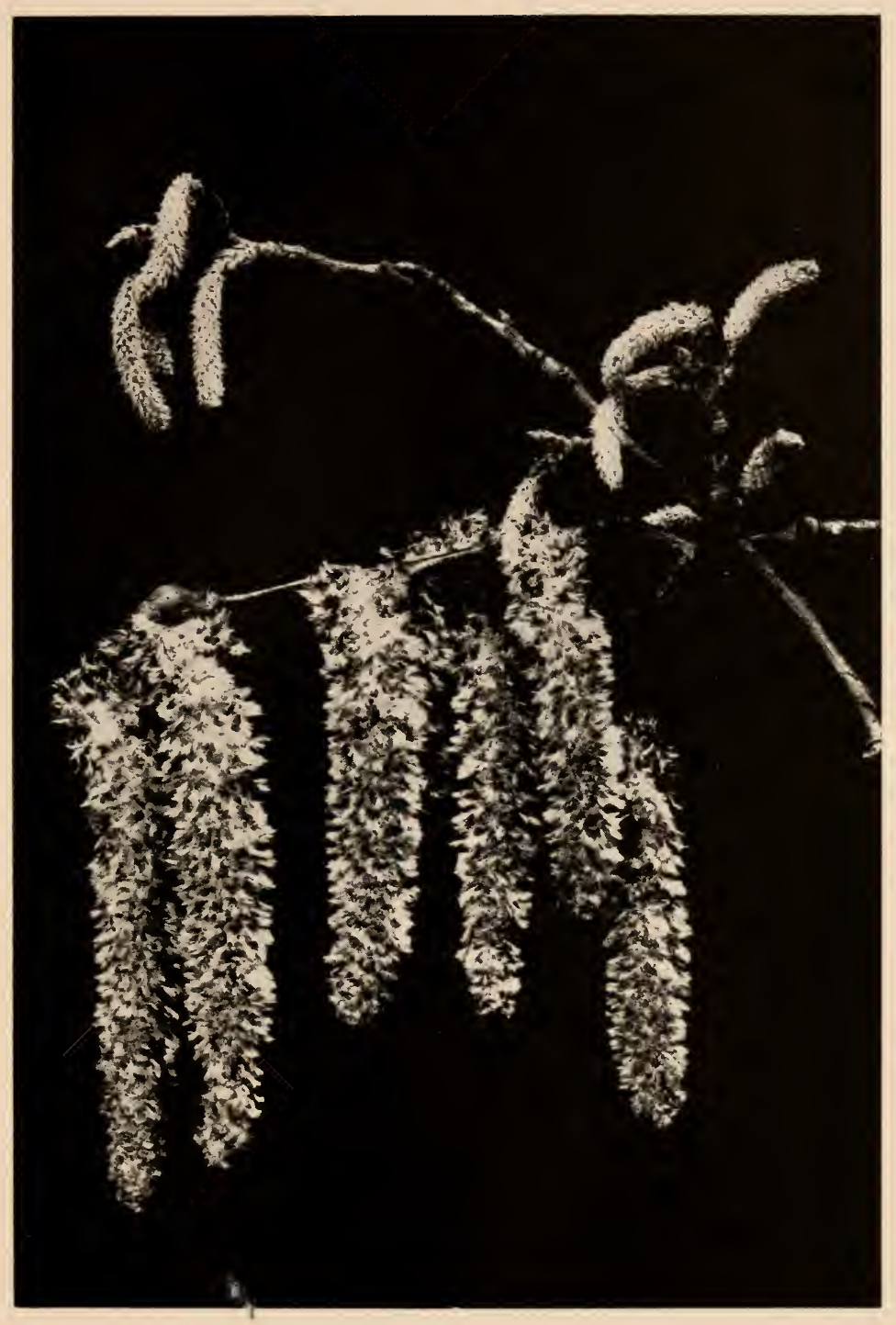

THE WHITE POPLAR WAS ALREADY AWAKE 

catkins, he had clothed himself in chenille tassels-each a string of tiny brown fans with pointed edges and silver fringes, with rosy clusters between-and hid his pale bark under a mantle of ashes-of-roses. However, the wind, shaking the pollen from the bright stamens, cried, "Pride must have a fall!'" and tore the tassels to tatters; so the poplars put on leaves lined with white flannel, which later turned to a silver lining.

Their cousin, the cottonwood, bore a tasseled banner of russet-red; though the vandal wind waved the bright banner too well, and all too soon Captain Cottonwood mourned his colors lying strewn upon the ground. But Mrs. Cottonwood was now stringing her emerald necklaces, and both dressed up in glossy leaves, which rustled in the wind like silken skirts.

Every morning some tree, adding a new flower to the spring, would ask, "Has Easter come?"

They were very busy, whispering and planning and working together, deciding on pretty 
designs and choosing becoming colors, and no little maid was ever more interested in her spring frock. Yet after all this talk and trouble, each tree chose the pattern that her mother used to wear, who had dressed as her mother dressed, and the pretty and varied styles at last ready for Easter were nothing new at all, for each fresh and smiling tree wore exactly the same sweet flowered pattern that her great-great-grandmother wore ever so many Easters ago.

So Easter morning eame, and when Polly had brightened her old dark-green dress with a new ribbon, she ran out of the gate and over the field, through the wood, to the home of Portia and Pearl. The carriage was at the door.

"We are going to church," said Portia. "Run back, little Polly, and put on your best dress."

But Polly had no best dress. She had hoped they would take her as she was, though when she saw Portia's tan suit and Pearl's pink freshness, she knew how plain was her own 


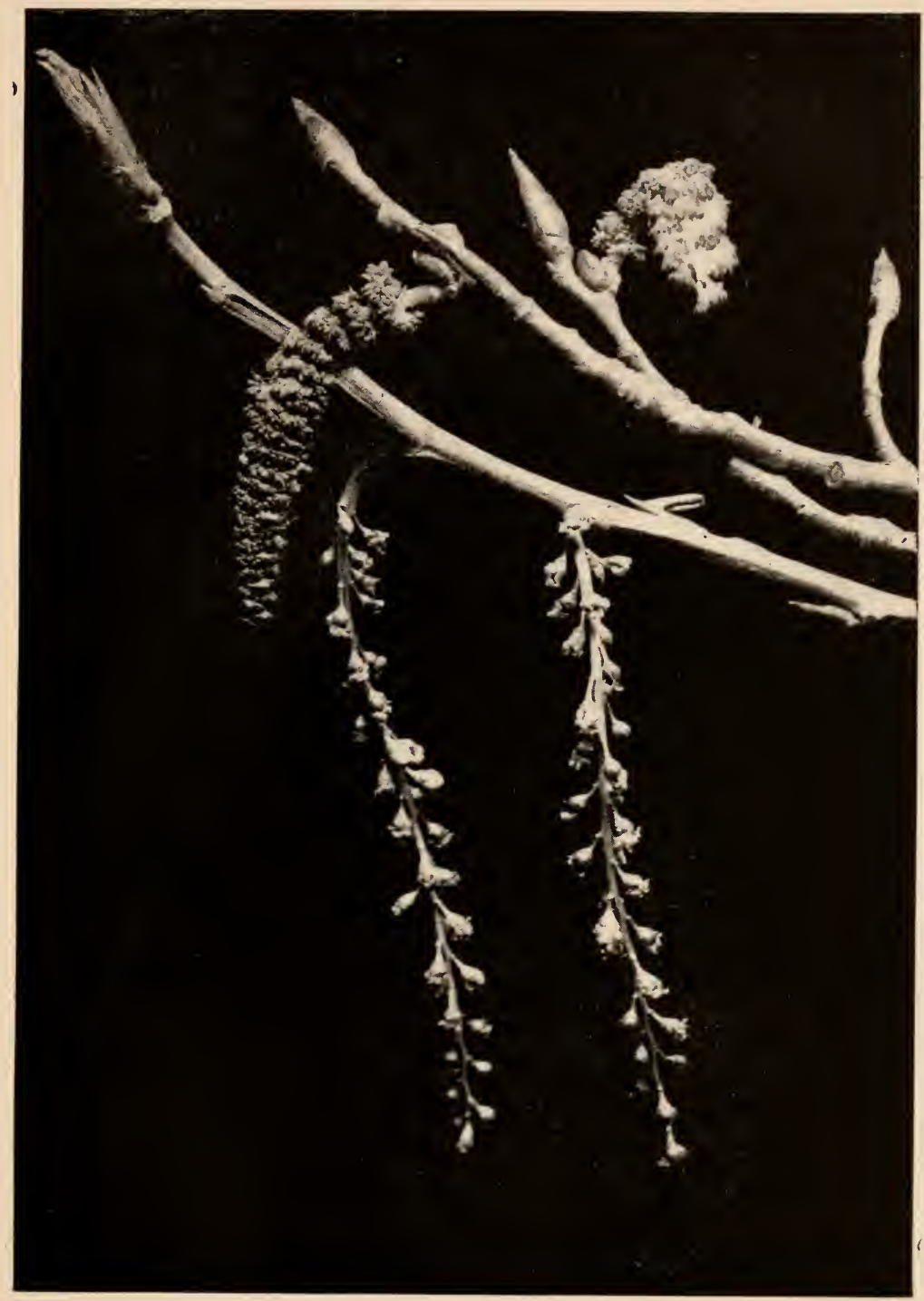

THE COTTONWOOD 

dark frock, as plain as that of the little evergreen tree near by.

"I will keep church in the woods," she said, smiling; "but when you come back, Portia, you must tell us what Easter means."

Then Portia and Pearl and their pretty mamma, like bright flowers looking forth from the dark winter bud, nodded to Polly as they wheeled away.

But at the gate the mother said, "Stop, and let us take Polly, too."

"She is not dressed for church," sighed Pearl.

The mother replied, "Polly, not Polly's dress, would see and hear and enjoy."

But Polly did not answer their call; she was huddled behind the fir tree, so like herself in its shabby green; though when she could no longer hear the lively wheels, down she tumbled in a little heap upon the ground and hid her face in the grass. Then, swallowing something very like a lump, she rubbed her blue eyes red, looked up, and saw-

Yes, it was Spring, though Polly never 
would have guessed if something had not told her; for Spring was not dressed in green. Through a silvery veil her yellow robe was all a-flutter with rosy ribbon caught up with coral clasps; only her sandals were green.

"Wake up, Polly!'" called Spring.

"Wake up, wake up!" echoed the robin.

But Polly was not asleep, though you are sure to think her dreaming. For miles around all had gone to church, so nobody saw what befell Polly when Spring came coaxing.

The robin interrupted them. "It is time," said he, "to judge which tree is fairest."

"Dear me," sighed Spring, "those that are not so very pretty will blame me. Still, there is a nice variety, don't you think so? Summer's wardrobe is only a green uniform, while mine is like the soft reflection of autumnal hues. Yet tell me, Polly, how should you look at the flowers of the trees to find out how beautiful they are?"

"Through a magnifying-glass," said Polly promptly.

Spring laughed. "Even so. I was going to 


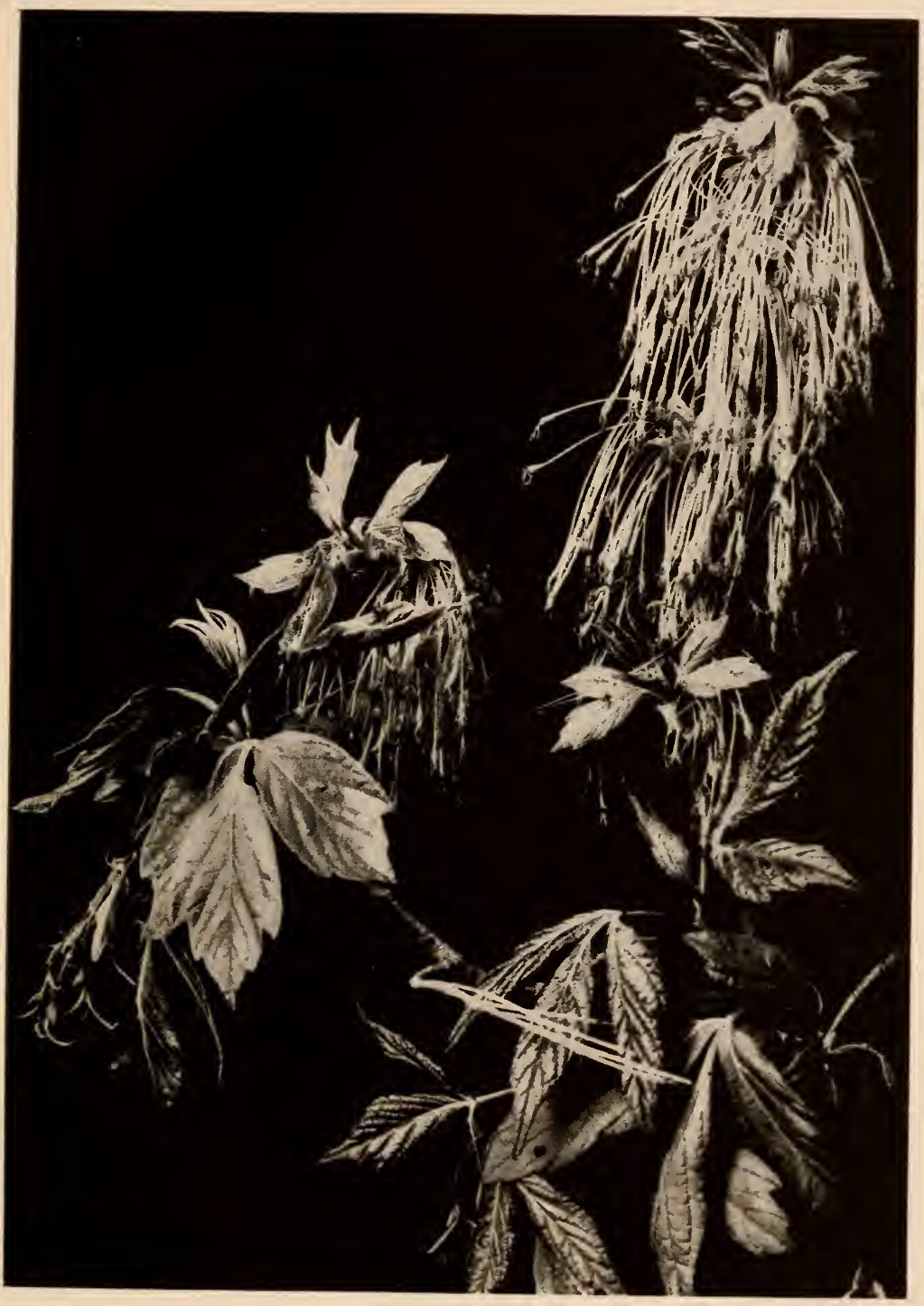

THE BOXELDER WAS GREEN 

say, with the eyes of love, but you have popped an idea into my head: I will turn you into a magnifying-glass."

Polly looked uneasy, pinching her chubby arm to see whether she was a little girl or a microscope.

"When you are a magnifying-glass," continued Spring, "you and the robin and the bee shall be the three judges to tell which tree is fairest."

Then Spring summoned a bee, and presto! before Polly knew it, she was no bigger than a bumblebee herself, sitting like a fairy queen between the wings of her new friend-quite safe from the sting-end, she was sure.

Up, up flew Polly and the bee, straight to the silver maple. But the silver maple had lost her flowers, and in their place winged seed hung like katydids under a flock of butterfly leaves.

The flowers of the red maple, too, had burned out, though all her seed were winged with flame.

Their sister, the boxelder, not so eager 
to bloom, had forgotten to pull out the old brown bastings of last year's gown.

"How untidy!" thought Polly, remembering.

However, the boxelder was green with leafy sprays and threadlike flowers, while her companion shimmered with silken tassels.

"They are beautiful, like floss," cried Polly.

"But remind me of lovely cornsilk," said the bee.

"Hush," breathed Polly, in a-flutter, "and listen to the music."

"Perhaps it is my buzzing that you hear," modestly returned the bee.

"No, no," cried Polly, clapping her hands and nearly sliding from the velvet back, "it is maple-music!"'

For the sugar maple was swinging out, on silken strands, a lot of little bells of sunlit green.

"I am clothed with Easter chimes," laughed she; "hear the zephyr ring my bells!"

"The very sweetest tree," spoke Polly. 


\section{A SYLVAN EASTER}

"O Polly, Polly," sighed the bee, sadly shaking her head, "I fear you have a fondness for maple sugar."

"And all the time," retorted Polly, "you are thinking of honey."

Which was quite true, for the bee turned nimbly to the Norway maple.

The Norway maple, a shining green, was dappled all over with clusters of stars.

"My stars radiate the joy of the springtime," she breathed.

"'Tis true," declared Polly, inhaling her perfumed breath, "and you are the sweetest of all!"'

"You know she is a foreigner," whispered the bee, flying to the American elm.

"After all," said the elm, "back of a smile lies the thought; and beyond the beauty of a flower lies its meaning, the seed."

"The elm is apologizing for her seedy garment," said the horsechestnut bluntly.

For the elm was covered with green samaras, each encircled by a gauzy wing, notched at the end and trimmed with silver fringe. 
"What beautiful bangles!" was Polly's thought.

The bee now flew down to the brook, where the white birch, veiling her pearly bark in green, was swinging her tassels of bronze and gold and studding her branches with emerald pins.

"Oh, the pretty, pretty birch," bubbled Polly, "how modestly she bends her head."

"Gazing at her reflection in the water," remarked her friend, turning to the silvery beauty of the beech tree.

The beech was unfurling her silky fans from their tortoiseshell cases and pricking her fluffy balls with green.

"I came near forgetting this," she said, tucking a little nut-flower near the tip of a branch.

"We are so glad that Easter is late this year," said the ash trees, putting on their green and purple plumes.

"However, I had to hurry more than usual," exclaimed the white oak, "in order to take charge of the services." 


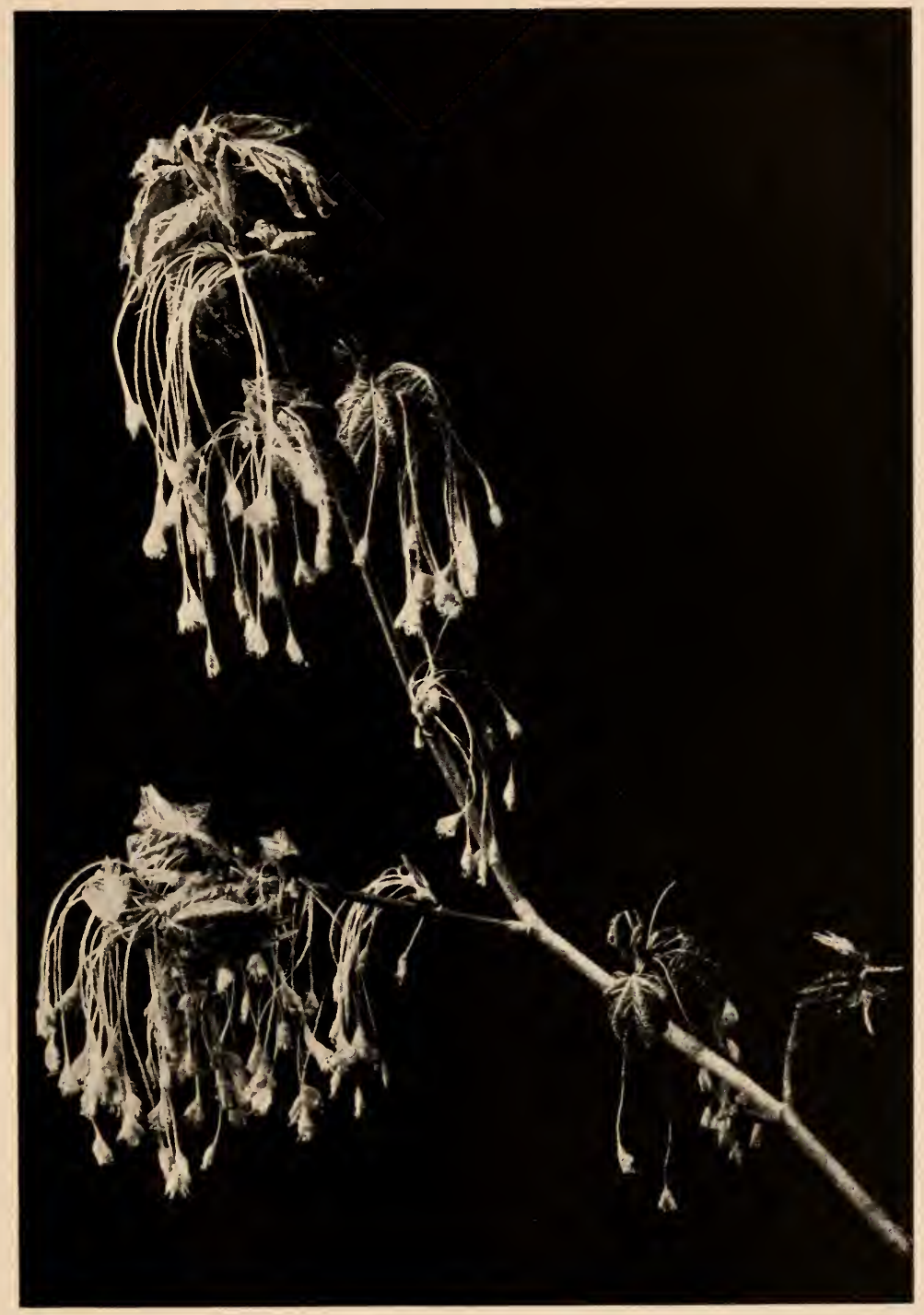

EASTER CHIMES 

And lo, the oak was clothed in fairy velvet vestments of pink and misty green, veiled in a shimmer of silver down and fringed with beaded tassels. Hidden in the axils of leaves were tiny round flowers, which would be acorns when velvet and fringes and silver sheen were only a memory of the pomp and glory of spring.

"Are you ready, are you ready?" called the robin.

"Oh, please wait till I finish my surplice!" cried the little dogwood, unfolding another large white rosette.

" 'Button, button, who's got the button?" " laughed the mottled sycamore, dangling her red and green balls.

But the bee had paused on her wanderings, well repaid by stolen sips of honey.

"Alas," exclaimed the horsechestnut, "my candles are not lighted!"

"And my white garlands are not ready!" lamented the locust.

"Nor are my golden chalices!" echoed the tulip-tree. 
"All too late," the linden sighed, "all too late I shall swing my ivory censers !"

"And I bear my altar flowers!" cried the catalpa.

"Kind thoughts are the true flowers of life," said the elm.

"Children," said the oak, "our bright spring raiment is fleeting, like the flush of dawn; our true and enduring beauty lies in the use for which this is but a joyful preparation."

Then all the trees in their fair attire, a congregation adorned for the Day, listened to the pontiff oak.

While flower-bells were ringing,

And perfumed censers swung,

The oak spoke from his pulpit,

With shining tassels hung.

Wood thrush and bluebird formed the choir; and the robin sounded the note that services were to begin-nay, were to continue, for they had begun long ago, when the first bud had expanded and unfolded at the matin bell of spring. 


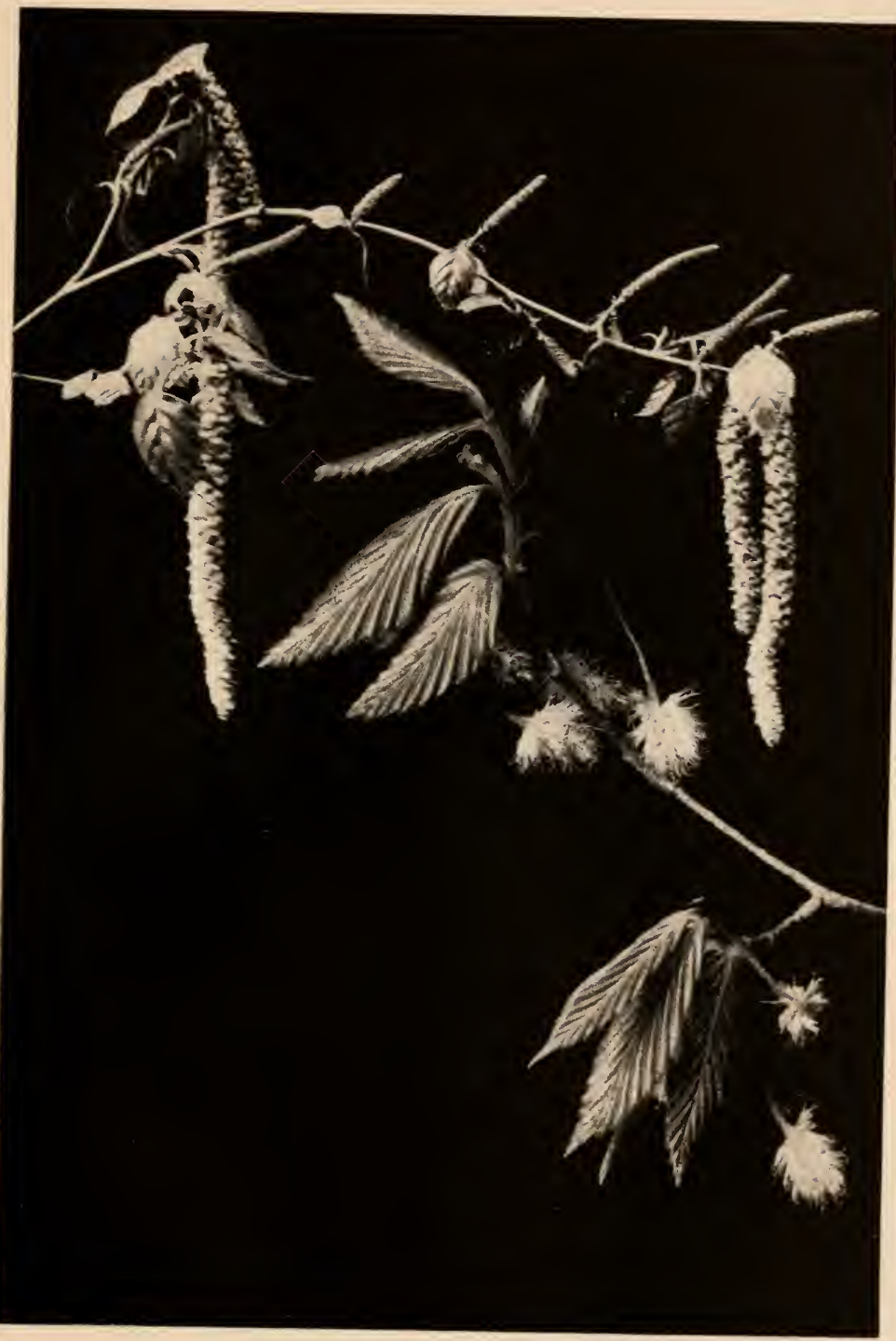

THE WHITE BIRCH AND THE BEECH TREE 

"We greet the year adorned with flowers," continued the oak. "Let none envy another, for remember that 'One star differeth from another in glory.' All help to make the season sweet, from the first gray catkin of the willow to the golden crown of chestnut bloom. We silently mark the passing of the bright hours of spring, and all who have not learned to tell the time of year by our flower-dial have bent their eyes too much upon the ground. When they learn to look up, they will find the trees telling how sweetly pass the sunlit hours, and will know that there is a benediction of flowers above their heads as well as flowers upon the ground crushed by their feet. Who that looks upon a tree adorned for the spring, can but 'Consider the lilies'? It is not vanity, but love, that clothes us, for we are making the earth beautiful for all, and consecrating ourselves to another year of usefulness."

As the oak paused, the robin repeated the praise of all the trees, and well he might, for where else could be found so fair a company? "The robin is right," said Spring. "I love 
them all, and find each in her own way beautiful."

"Yes, I, for one, cannot choose the prettiest tree, for I, too, love them all!" cried the bee, and dived right into the heart of a violetforgetful of Polly upon her back, who was brushed off and bumped upon the ground.

There she sat, rubbing her eyes and looking about her, grown big again and just the same Polly that she ever was, and were it not for the pollen on her dress, she might have thought it all a dream-though she was rolling among the dandelions, it is true.

There was the sound of wheels upon the road, and here were Portia and Pearl.

But where was Spring? Everywhere-lips laughing from rosy buds, cheeks glowing from ruddy leaves, hair shining in yellow catkins.

"O Polly, Polly!" laughed Pearl and Portia, running up.

"I don't care," said Polly, jumping up and shaking herself out from her tangle, "the bee knocked me right over." 
"O Polly, silly, silly Polly," sighed Portia, "dreaming of bumblebees."

"I'm not silly," declared Polly, "and if you had heard what the oak was preaching, you'd be as wise as $I$ am now. As for the bee-oh, there she goes!"

Then Polly smiled to herself as she settled down under the sunrise oak, clasping in her chubby hand the lily which they had brought her, while Portia told the real meaning of Easter.

"Easter is our awakening into a new and higher life. We may lay aside old garments of the mind, as we do of the body, and clothe ourselves with a new spirit; for the true Easter adornment is within, of which the outer ornament is but a symbol. So on this Easter Day let us blossom into a better, brighter life and show the Divinity within, even as the trees are showing that hidden within them lies the power to burst hard buds and proclaim with flower and leaf that life of which winter could not rob them, which is one Life, one Thought in all," 


\section{DOGWOOD IN BLOOMI}

Oh, cold was my shift in winter!

Oh, white was my shroud of snow!

Nay, soft was my robe of slumber,

For I was asleep, you know.

You carved of the ice my caskct-

$\mathrm{O}$ cradle of crystal light!

While roughly the wind was rocking,

I dreamed to my heart's delight.

Old Boreas' blowing bore you

The dolor of dirge and sigh:

The wind all the while was whistling

My sleepytime lullaby.

You saw in the frost enamel

The seal of the silent hours:

The frost that impearled my branches

Was only my dream of flowers!

Whatever the thrall of winter,

Whatever the thought it bring,

I weave from that pall of whiteness

The surplice I wear in spring !

The soul of the marble statue, Though chiseled in storm and strife,

I wake to the truth I dreamed ofThe beauty and joy of life! 


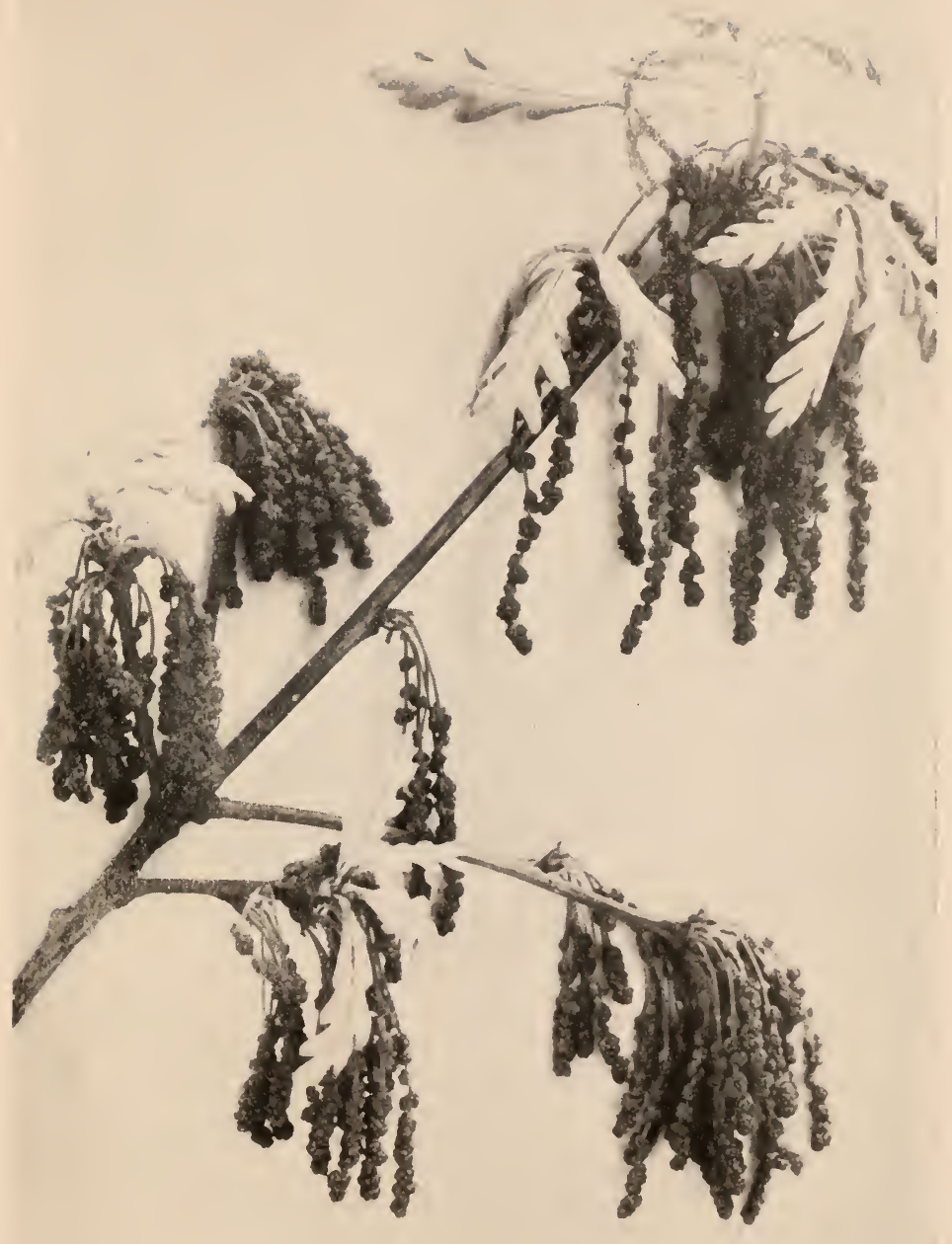

THE POMP AND GLORY OF SPRING 



\section{THE LINDEN-TREE OF JONSBODA}



- 


\section{THE LINDEN-TREE OF JONSBODA}

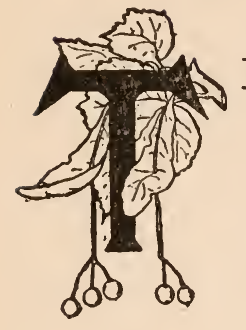

HERE was once a large and beautiful linden-tree, for which tradition had won the name of the Holy Tree. For many years, longer than anyone could remember, it had stood on a farm in Jonsboda, Smaland, in the south of Sweden. Misfortune would surely follow him who harmed the tree; so, safeguarded by adoration and fear, in the seventeenth century it still lived on the farm of Ingemar Svenson, a real family tree. Under the heavy shade played Ingemar's three children, repeating the traditions that they had heard about it, and loving it for the sake of these stories, for the kind shelter of its heart-shaped leaves, and for the sweetness of its summer bloom.

The three children grew up, loving the tree 75 
as naturally as they loved one another. Yet to Ingemar's little daughter there often came a dream of the linden-tree; her ears seemed to eatch a voice when the wind stirred its leafy boughs, and her eyes saw more than creamy petals in the sweet surprise of scented flowers. Always her dream filled her heart when the linden flowers were budding-a dream that came she knew not whence, a dream of something that the linden-tree was trying to tell with unfolding flower, until the secret was lost in the very sweetness of its breath.

Her two brothers studied for the priesthood. Instead of being called Carl and Sven Ingemarson (son of Ingemar), they chose a new surname, right from the family tree. Tilia, the linden-tree's classical name, and andros, Greek for man, gave them Tiliander -linden-tree man.

But the old linden-tree, not content to name the boys, whispered something to Ingemar's daughter, and repeated it on her wedding day. She married a farmer, Ingemar Bengtson, and they had one son, named Nils. 
When Nils studied for the priesthood and looked for a surname, the linden-tree named him Linnæus. There was another linden family name-Lindelius. The linden-tree had three branches, one for each linden name, and it was said that when the last male heir to each name died, one branch withered and was no more.

The day that the linden named young Nils was a proud day for the old tree. Yet what was the message that the linden had given Ingemar's daughter? She was a mother now; and her son heard the same faint message, wondering what the linden-tree's meaning to the family was, beyond a name.

There was a beautiful garden at the parsonage of Sven Tiliander, where Nils studied with his cousins, and when Nils was pastor at Rashult he also had a garden of wonderful plants. His young wife, Christina, from the barren north, dearly loved these southern flowers, and eagerly welcomed signs of spring.

Meanwhile the old homestead linden was opening coral buds and unfolding emerald 
leaves. Under the leaves grew long applegreen bracts and from the center of each feather-shaped bract hung a spray of little round buds, swelling in the softening air, growing larger and fairer day by day. But on the twenty-third of May, in the year 1707, long before these buds were ready to burst into pale blossoms, the wind brought the old linden-tree word from Rashult that a new flower had bloomed and lay on the breast of Christina. The child was named Carl. His father decked his cradle with flowers, his mother would quiet him with a blossom.

By-and-by the family, and the family flowers, all moved to the beautiful parish of Strenbrohult, and in the new garden little Carl learned to walk. Soon he was talking to the flowers: Did not they, too, have their faces washed? The dew did it, and the sun dried them and kissed them and told them to be good. He was called Carl; they also had names. They were always dressed the same, but did they think he was another little boy every time he wore a different dress? If he had 
a flower-bed all his own, he was sure that his flowers would always know him, as he knew them; so his mother and father, who were just like all mothers and fathers, let Carl have his own little plot, which contained one specimen of all that grew in the garden.

One day Carl went to a country fair, and in the evening a little group sat around upon the grass while his father told the folk all about their neighbors, the native plants-not knowing what trouble he was storing up for himself; for "Little pitchers have big ears," and Carl sat very quiet, listening with all his might. Afterwards, it was "Father, this," and "Father, that," until Father could tell no more. When Carl failed to remember the answers, his father would preach a.little sermon to a small and select audience of one, to the end that there must be no more questions until answers were remembered, and this, perhaps, was as good a lesson as one in botany.

Carl loved to wander through field and wood, where he found plants to press, or to plant in the little plot now known as "Carl's 
garden." But while his wild plants were overrunning the family garden, and the wild bees that he brought home were besieging the domestic hives, his mother was busily planning the future of her "Little Botany Boy." She chose him for the church. There is a story told* of how one day his mother found him with the loved family Bible, and her heart bounded with joy that her long-cherished dream might come true; but no, he was pressing some new-found flowers therein.

“ 'Dear child,' she said, 'you must not put herbs and flowers in my beautiful book. It would be quite a sin to spoil the Holy Bible.'

" 'Pray forgive me, Mother! But these are the most beautiful flowers I have ever seen, so I thought I would preserve them best of all, for I have heard both you and Father say that the Bible is the Book of Life; and surely, if I put the flowers between its leaves, they will retain their color, the Bible keeping them alive forever.'

" "The Floral King," by Albert Alberg. 
" 'Child, when we call the Bible the Book of Life, we mean by that, not the life we see before us, but the spiritual growth of our souls, for every thought we think is a flower culled in the garden of our soul. There, as on earth, grow many various plants, some of wondrous beauty, and others stained with sin. But every time we humbly read in the Sacred Writ, a seed is sown in our heart, which some day will bloom, and bear holy fruit.'

" 'How beautifully you talk, Mother!'

"'Well, you must diligently read your Bible, and in your heart will grow the seed of goodness and humility; but I fear-_

" 'What do you fear, Mother?'

" 'I fear you love the fair flowers of the earth too much to care for the seeds that were watered with tears in the Garden of Gethsemane.'

" 'O Mother, no, I won't forget my Bible. But when I see a flower I think this way. Why does God make the cold, damp earth grow such lovely creatures with such beautiful colors? Why, if not to make us happy 
with the sight? And then I fancy the flowers saying with their petaled lips, "Look at us, and think how kind and good is God." 0 Mother, every flower must have been a thought of God.'

"'Why, how you speak, child! Well, yes you are right, it must be so." ",

But Carl was now a big boy-eight years old -high time that he gave his thoughts to serious study, so for two years he suffered under a tutor. Then one day his mother tearfully packed his little belongings, and started him off to school at Wexiö, where at the end of eight years his teachers said, "Apprentice him to a shoemaker." He was only bright in natural history - though what had this to do with shoes?

Now this was not at all encouraging. Carl was the eldest of five children, and his father felt sorely perplexed. He stopped in to see Dr. Rothman, in Wexiö, and told him what troubled his mind as well as what troubled his body-the very best thing that he could have done. 


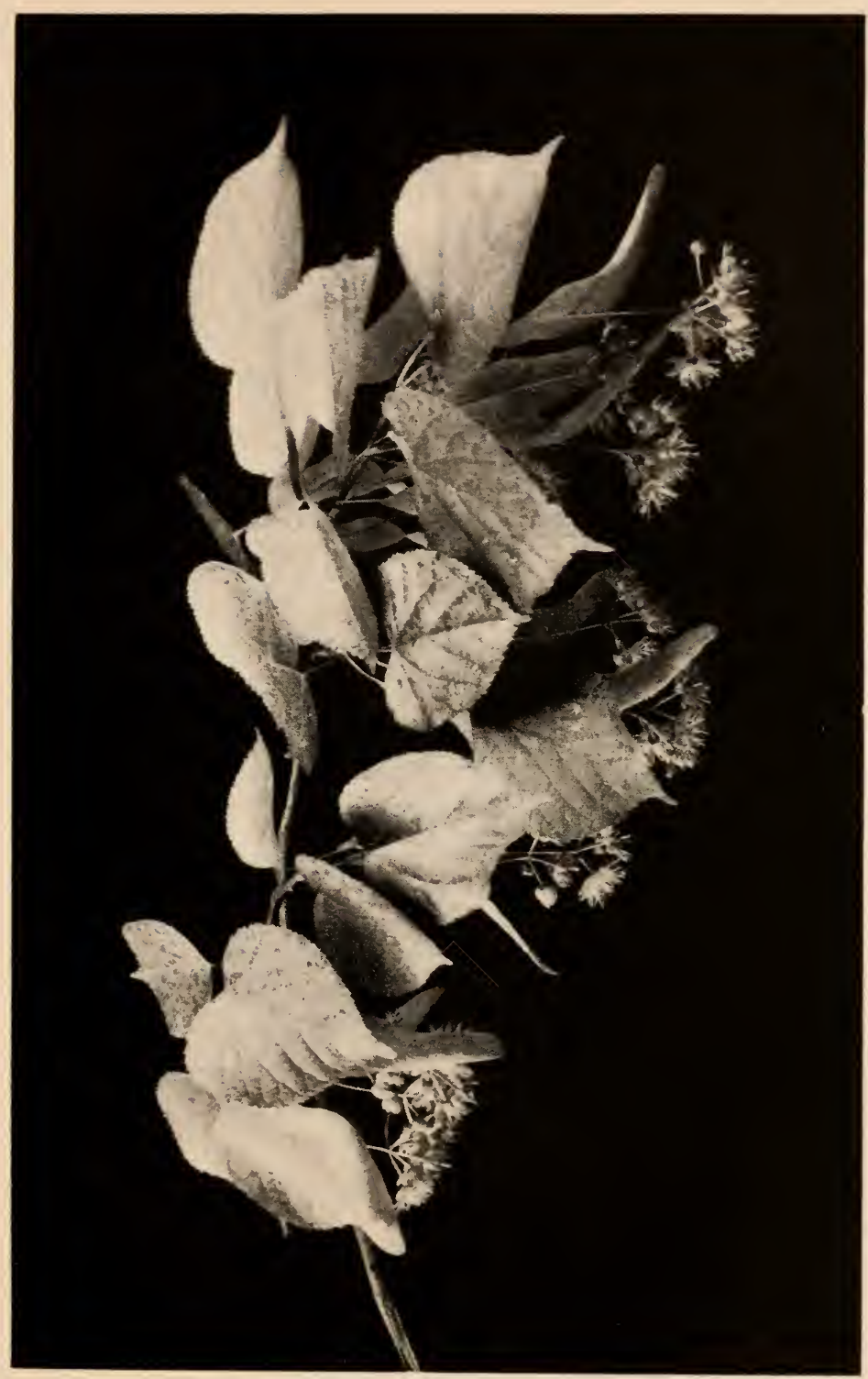

THE SWEETNESS OF ITS SUMIIER BLOOM 

"I guess that that is really what is the matter with you," the Wexiö doctor said, "While as for the boy-well, it isn't such a bad symptom for him to love natural history. Send him to me. I'll turn him into a doctor."

And he offered to provide for him, if his father could not, while he finished his course at the "Gymnasium" or Latin school. And so Carl found his first fairy godfather. For one good, glad year he studied under Dr. Rothman, and then he was ready for the University. of Lund.

"Ah, it is all very well," sighed his mother, when they told her that her first-born was not to serve God through the church. "Ah, yes," and she glanced at Samuel, her second son, "But he shall not waste his time on so idle a study as herbs and flowers!"

Carl started to Lund with this letter of recommendation from the Wexiö school:

"The youths in schools may be likened unto young saplings in a plantation, where it sometimes happens, although seldom, that young trees, despite the great care bestowed upon 
them, will not improve by being engrafted, but continue like wild untrained stems, and when they are finally removed and transplanted, they change their wild nature, and become beautiful trees that bear excellent fruit. In which this respect, and no other, this youth is now promoted to the University, where, perhaps, he may come to a clime that will favor his further development."

At Lund Carl lodged with Dr. Stobæus. Dr. Stobæus had a fine museum and a library from which a fellow student secretly lent Carl books.

Now the good old mother of Dr. Stobæus, who was infirm and ailing and not inclined to sleep, knew that something was wrong. Could she not see a light burning in young Linnæus' room long after a youth of twenty should be in bed? "We are flying in the face of Providence," she told her son, "and inviting fire."

He promised, in his old-time, obedient way, to quiet her fears by investigating their cause. So one night, at two o'clock, he stole softly up to Carl's room-and was himself taken by sur- 
prise. There sat Carl-surrounded by big books of botany.

"Young man," the doctor sternly asked, tapping the truant books, "where did you get these?"

Carl confessed.

"Well, well, well," the doctor growled. "And now, young man, go to bed."

Early in the morning, Dr. Stobæus sent for the culprit, who went with a heavy heart. But there, sitting in the stern doctor's chair, he found his second fairy godfather. The doctor's museum, his library, and his love were Carl's forevermore. Yes, the lad was to join them at the family table, too, and so he became as a son in the house.

The pleasant school year passed away, the last at Lund, for when home on his vacation, Dr. Rothman said, "Now you must go to Upsala."

Carl, the poor student, entered Upsala, the oldest seat of Swedish learning, little knowing the glory that he was one day to shed over this great University. It was a daring leap, for 
coins were few and meals came by chance. Yet perhaps he remembered, "Poverty is the attendant of a good mind," as he sat mending his poor shoes with folded paper.

One day Carl went into the University garden to examine some plants. There he forgot that he was hungry, he forgot his mended shoes. While he was communing with the flowers, an old man entered the garden-a man of note, he seemed to be. He shot some gruff questions at Carl: "What are you doing here? Where did you come from?"

Carl was so shabby, he did not wonder at the questions.

"Are you acquainted with plants?" continued the old man. "How long have you been studying?"

Carl lifted his eyes-dark, beautiful, penetrating-from the flowers to his questioner, and answered bravely and well. The stranger looked surprised-this poor youth displayed much knowledge of botany. And lo, to Carl the garden suddenly became enchanted, and the old man was transformed into his third 
fairy godfather, who said, "Follow me." So Carl followed him home and henceforth Dr. Celsius was the best loved of all his fairy godfathers.

Pupils now came to Carl. He wrote a short essay showing a new way of classifying plants, and was able to give lectures on botany.

After awhile it was decided that Carl should go on a long and lonely journey to find out more about the northern plants. This awoke the fears of his mother, who urged:

"In thine own land live and dwell, Working there with humble faith;

God will then provide thee well."

Yet with a larger faith his father wrote: "If you think it will lead to your future advancement, then pray that God may help you in this. He is omnipresent, even among the desolate Alps."

So Carl set out on his wonderful journey, over mountain, through bog, and by boat, to beyond the Arctic Circle. But at last, after five months of mishaps, he came back safe and sound. 
And now every one wanted to hear him; but as he had no big letters after his name which meant a doctor's degree, he had to give up the lectures.

Nothing daunted, Carl set out on a little journey to collect plants. One day he stopped at the house of Dr. Moræus, who had two daughters, with one of whom he straightway fell in love.

But Father Moræus said, "No degree, no daughter." So once more Carl set out, and though he could not speak Dutch, he went to Holland, where he won his degree and found his fourth fairy godfather. George Cliffort, a rich burgomaster, gave him the care of his body, his gardens, and museum. Carl lived in luxury, like a son of the house, published his first five books on botany, and became famous.

England, France, Holland, all wanted him to stay, but he returned to his cold northern home to receive the blessing of his father-his mother had not lived to know the fame of her "Little Botany Boy." In Stockholm he tacked up his doctor's sign, and hither, in the 
month of roses, he brought his Sara Lisa.

At first Carl Linnæus found himself "a prophet without honor in his own country." It is true that as a doctor, he was making money; but "he was fonder of meddling with plants than with patients." Still did he long to be "a Priest of Flora"; and three years later, he was offered the Chair of Botany in Upsala, in which he sat for thirty long and happy years, lecturing, and writing books on plants, animals and minerals-books that made him his country's pride.

When Carl began the study of botany, he found a number of rather crude ways of classifying plants. He made a new system of plant relationship, based on the pistils and stamens of flowers. He shortened the long Latin names, giving each plant a clear, concise description. He classified animals and minerals, too, and is called "the Lawgiver of Natural History."

Carl gave the University such a name that students flocked from near and far. Science showered him with honors, medals were struck in his name, and King Frederick made him a 
Knight of the Polar Star and a noble of the land. He took for his erest three crowns on three fields, emblematic of the Three Kingdoms of Nature, the hemlet bore his favorite flower.

Did the old linden-tree dream of the honors done one of the linden-named? Perhaps the wind or the bees brought word, though the linden-tree must have known it before, and that was the message that she had been trying to tell.

And so the years passed, silvering the hair of the "Little Botany Boy," yet he ever kept the brilliant eyes and the alertriess of his youth, and that love of order, promptness, and regularity which, with unfaltering faith, had accomplished his life work.

Then for six years he rested as an invalid from his labors. Carl, the eldest of his six children, sat in his Chair of Botany. When he could no longer walk, he would be carried to his museum, and the treasures that had come from the north and the south and the east and the west would repeat their stories over and 
over, and again Carl would thank God that "He had permitted him to visit His secret council chambers."

In the white dawn of the year 1778, when he was three-score years and ten, while the old linden-tree was sleeping and the linden blossoms lived only in the dreams of those who loved them, Carl Linnæus, born with spring flowers, now too restless to wait for their sweet encouragement, picked up his staff once more and set out alone on his last and most wonderful journey of all. And so he found his "fields of asphodel." 



\section{FOREST LEAVES}





\section{FOREST LEAVES}

\section{1.-The Little Spruce Tree}

AR up on a mountain a baby spruce seed cuddled with her little sisters, two and two, in a cone cradle, while to the wind's Rock-a-by,

the mother-tree swung them to sleep on the waving bough. Yet all the time, in the snug darkness, this little seed lay wondering what was outside of the cradle, for something must lie beyond it, she was sure; and one day, as if in answer to her longing to know, the wind loosened her scale coverlet and tossed her out, like a young bird pushed from its nest to fly.

Borne lightly on the wind, slowly down, down, down, she sailed through the frosty air, with her one gauzy wing to buoy her up, like 
hope, till far below, on the slope of the mountain, a resting place was found; and here, weary from her long way on the wind, the little seed laid her irridescent wing to rest forevermore, and fell asleep.

In the very spot where the little seed fell asleep, a tiny red spruce tree awoke with the spring. The sunlight was tempered by the sheltering boughs of an old black spruce, whose plainness was beautified by kindliness as she said, "My daughter, I welcome you to the forest!"

And the little tree looked up and called her "Mother."

Lifting her pretty head still higher, the little spruce tree gazed curiously around her forest home. "This must be that world which I have always longed to know," thought she. "How green and wonderful it is; I shall stay here content forever."

Forest neighbors crowded the little stranger on all sides; and in her heart she felt a kinship with the evergreen trees, large and small.

"But who are these?" she asked, for there 
were other trees, whose odd fashions she did not understand.

"They are maples," answered the black spruce.

Every autumn, as the changing seasons came and went, the maple leaves flushed and fell to the ground; but in the spring the buds on the bare branches would redden and part like smiling lips, until all the maples were laughing with bright flowers. After spring flowers came summer green, when the little spruce tree would glance ruefully at her old dress, worn so many seasons.

"I should think," said a dainty maple, "that you would spruce up when spring comes."

So she trimmed the old gown with new frills of green, though these made it dingy by contrast.

"Do not forget," the old spruce consoled her, as the little tree gazed wistfully at the bright new dresses of the maples, "do not forget that all through snowtime you helped to keep the forest green." 
"Yes, I remember," cried the little tree, brightening; "and men with horses and sleds carried away many little evergreen trees. Tell me, where did they go?"

"Out into the great world," replied the old spruce.

" "The great world," " repeated the little spruce; "is not this beautiful forest all? Does something still lie beyond?"

"Something still lies beyond," answered the old tree.

"And what do the little evergreen trees do out in the great world?"

"They gladden the hearts of children on Christmas day."

"Shall I ever ride out of the forest, into the heart of a child?" eagerly asked the little tree.

"Look as pretty as you can, and perhaps you will go on that wonderful ride."

So the little spruce tree grew like a beautiful green pyramid; yet every winter the men with sleds passed her by; and at last the old spruce said, "Be content to grow and hang 


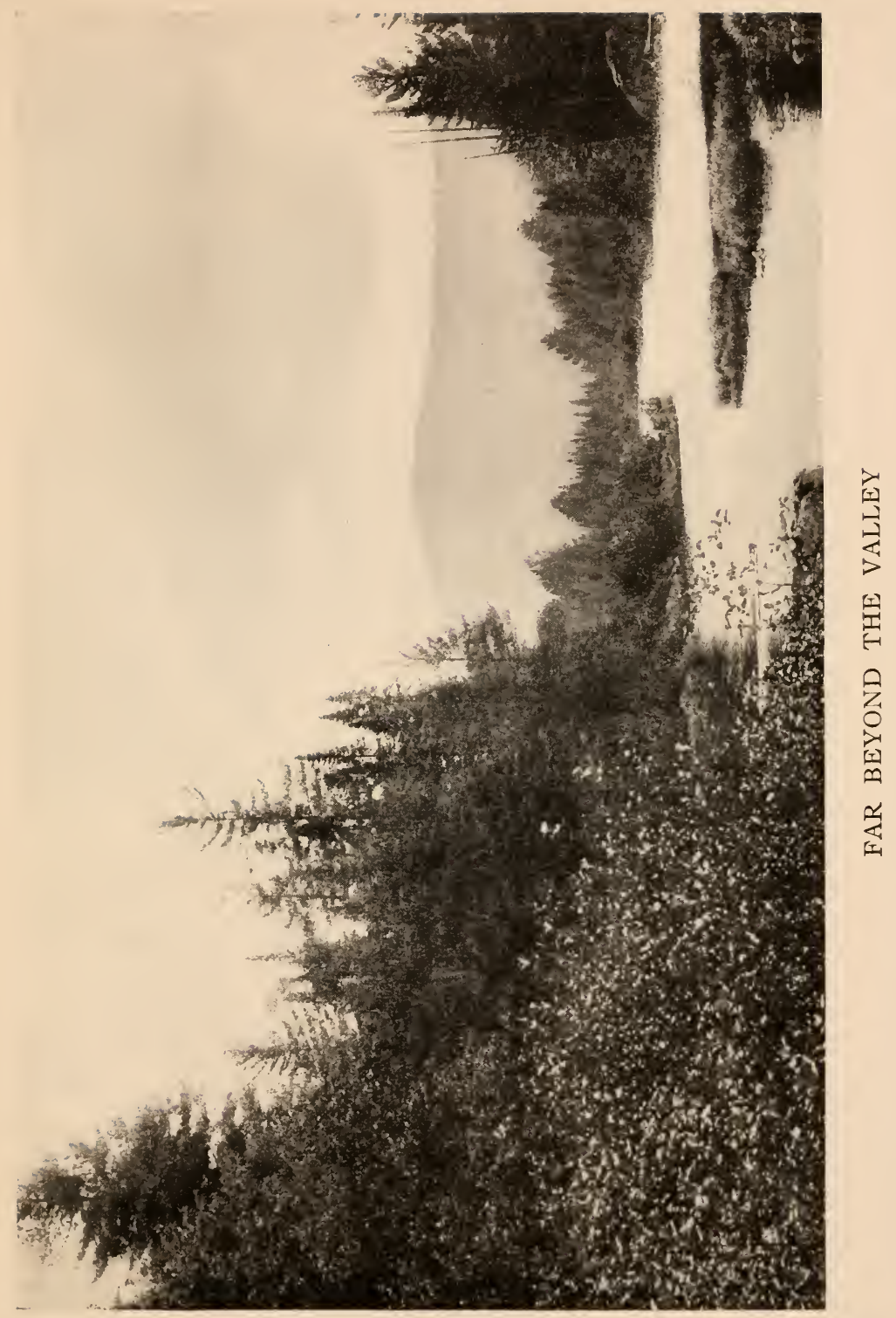



your boughs with cones, which will last much longer than the colored candles on a Christmas tree."

"I will grow and grow and grow till I touch the stars I" cried the little tree, and lifted her head higher and higher and grew so tall that her green garment no longer swept the ground, for her slender stem was like a column, and she wore her branches like a crown. In time no other tree shut out the sunlight or the sight of the stars.

"Oh, if I could reach you!" she would cry, when the snow lay deep about her feet and the stars sparkled in the sky.

The only music on these winter nights was the song of the spruce trees, though sometimes the maples talked in their sleep when the wind jostled them too roughly. Yet often the little spruce tree could hear another sound, like a far-away call from the valley.

"What is that in the valley, and whom is it calling?" she asked.

"It is the river," replied the old spruce, "calling the trees to come." 
"The river? Where will the river take the trees?"

But the old tree trembled. "It is well to abide in the forest," said she, "with a hundred years of life."

"Just one more question," said the little spruce again; "do the trees answer the river's call ?"

"Grow taller," replied the old tree, "and you can see for yourself."

But one day a storm arose, and many spruce trees lost their footing on the mountain side and fell. The little spruce tree could now see the river, and far beyond the valley to the distant mountains, where other spruce trees, thousands of them, grew.

"What a wide, wide world!" she cried, and at night hearkened no more to the river, but listened to the ceaseless song of the spruce trees borne by the wind across the valley.

"What are they singing?" she asked.

"They are restless," was the reply; "they long to dance to the river's playing. Heed them not." 
But the little spruce tree could not shut out the song of the discontented trees. She listened to the lure of the river, "Come, dance with me!" and their eager reply, "We are coming, we are coming!"

And then she saw that the trees really did go with the river, for men came and chopped them down and hewed off their branches and floated them down the current; and she wondered what that great world was like to which the Christmas trees had gone and whither the river was hurrying down the valley, bearing with it the spruce trees from the mountains.

\section{II.-The Poet}

One summer day a young man climbed the mountain side, wearily, as if weights were on his feet, and as he lifted his eyes to the spruce tree, she saw that his heart was heavy in his breast.

"The mountain is not so steep," she reproved him, "that you need drag yourself up in that way." 
Though the young man was a poet, he could not understand the language of a tree; yet in his soul he felt her gentle reproof and hastened his lagging steps.

"Come, rest under my branches," she whispered.

And this he did, and for a long while stood gazing through the evergreen forest to the far mountain.

"How fast the trees are hurrying," said he, "out into the world!"

"What will the trees do out in the world?" asked the spruce tree eagerly.

Still musingly he continued, "They will bear news to the homes of men; I would they might bear my message to the hearts of men!"

"Do spruce trees bear news and messages as well as cones?' she questioned.

His troubled eyes sought her murmuring boughs, and he listened to catch her words.

"Lie here and rest," breathed the spruce tree; so he cast himself upon the ground, rested his head upon his clasped hands, and gazed up into her whispering branches. 


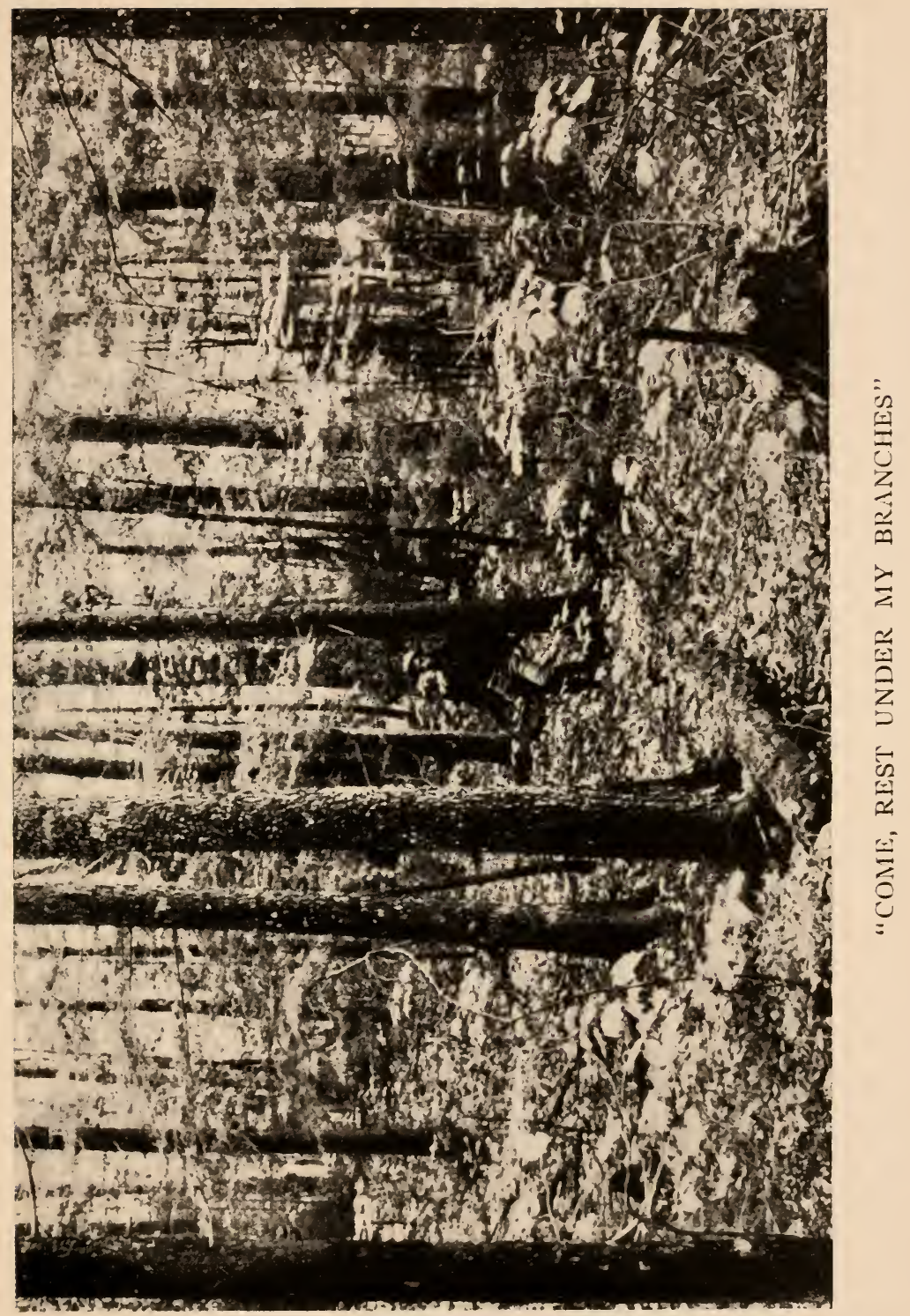



"Some good fairy must have led me to you, beautiful child of the forest," he said to her. "Let me talk to you awhile and listen to what you have to tell.

"Picea-for is not that your classical name? -Picea, we are alike, you and I; you are one tree in a great forest, while $I$ am like a tree in a forest of men; yet though you are happy and do your part willingly, I am not content simply to serve in the place where I find myself.

"Picea, if you and I had been cut off in our early days, you would have been a Christmas tree and I should have been a cherub; but we have been spared for some other purpose. Let us hope that our best use will find us out. Would you be willing to go out into the world should the world have need of you?"

"Should I leave my green boughs behind ?" she asked. "The little Christmas trees went as they were."

"You would leave your tree-garb behind," he said, not knowing that he answered her. "Picea, should you like to bear the record 
of Man's doing and undoing upon your white bosom? For most spruce trees go forth into the world as paper. Sometimes more than twenty acres of the spruce sisterhood are changed into the newspaper of a single day. Yet after all, a newspaper lives but a day."

"Only one day!" repeated Picea. "The little gauzy insects flying in the summer sunlight, live as long as that!"

"A newspaper lives but a day," he continued, "but a good book lives forever!"

And her murmuring branches echoed, " $\mathrm{A}$ good book lives forever!"

He started at the touch of a falling cone.

"The wind almost makes you talk. Picea, I am a poet, and that is how I know you have a soul. Yes, I see more than a tree beneath your brown bark and green branches: I see a friend, one who serves mankind. And yet, Picea, I love you for yourself alone, and for your message given me this summer afternoon; for in the restlessness of my life in the world I had lost the faith which here I have found again-the faith that the same Care 
that safely enfolds the spruce seed in the cone until it is time for it to fly, and then wings it for flight, will guide us to our best use. The seed does not question nor worry nor fear, but obeys the wind that blows it and the spring that calls it to awake."

Taking a notebook from his pocket, he wrote:

If in this form, a forest tree, God's purpose be fulfilled in me, Then is my part of His great plan To be the finest tree I can.

He laughed and tossed aside the leaf, yet Picea had heard the words and was happy. For all the while as he lay on the soft moss and leaves this was the unceasing murmur of her boughs, and now he had found the peace born in her in the forest home. The Indian who is in doubt goes solitary into the forest. Solitary? He returns, satisfied, and says he has talked with the Great Spirit.

The young man sprang lightly to his feet. Laying his hand lovingly upon the rough, flaking scales of her brown bark, "Picea," he said 
gravely, "I believe that you and I will meet again. It may not be in this forest; but somewhere, some day, somehow, you and I will meet again!"

\section{III.-The Paper Nest}

The sun slipped back of the mountain and night settled down, but Picea could not sleep, though she seemed to be dreaming under the silver coverlet of moonlight.

"Perhaps I am not always to be a tree," she whispered to the night wind.

"Sleep, little tree," said the old spruce, though Picea was now almost as tall as she. "All too soon the change may come. When I was a little seed, I slept content in the sheltering cone until it was time to be a tree, though it seemed a long, long while. This same trust I have ever tried to teach you since the wind brought you to the shelter of my boughs."

"You have been a good foster-mother," said Picea, softly.

"Only a nurse-tree!" laughed a pretty little 


\section{FOREST LEAVES}

red spruce. "It is so stylish to have a black nurse!"

"That was the part given me to fulfill," the black spruce patiently replied.

"I shall always call you 'Mother,', said Picea, lovingly, "and I hope that I may do my part as well as you have done yours."

"Sleep, little one," repeated the old tree; but in the morning she heard a question:

"Mother, was paper always made from trees ?"

"No, my child; many vegetable fibers have been used to make it, though now it is made chiefly of wood-so a bookworm told me."

Vespa, the wasp, was grinding off shreds from an old log with her mandibles and working them in her moist jaws, to add to the edge of her ever-growing nest.

As she pressed and kneaded the pellet into a cord with her forelegs, she said, "I was the very first to make paper out of wood. For a long while only the Chinese knew how it was done. Then about two centuries ago," she continued, when she had drawn the cord through 
her mandibles and flattened it into a strip of paper, "one named Reaumur noticed me at work. He did not 'go to the ant,' but went to the wasp and considered her ways; and now a great Man-made wasp, with sharp steel mandibles and iron jaws, sits upon the river bank, making paper out of wood. Man calls the wasp a mill."

As the summer days passed, Picea watched Vespa making paper. When the chill, wet days of autumn came, Vespa flew away and did not return. Her work was done.

As the last bright leaves of the maples fell to the ground, Picea's neighbors called sleepily, "Good-night!"

"Good-night," responded Picea, " and goodbye!"

"Why 'Good-bye'?" asked a little maple drowsily.

Picea looked wistfully through the evergreen forest, intermixed with the fading foliage of the hardwood trees, with here and there a bright autumnal torch that the north wind had not blown out, and sighed. She leaned her 


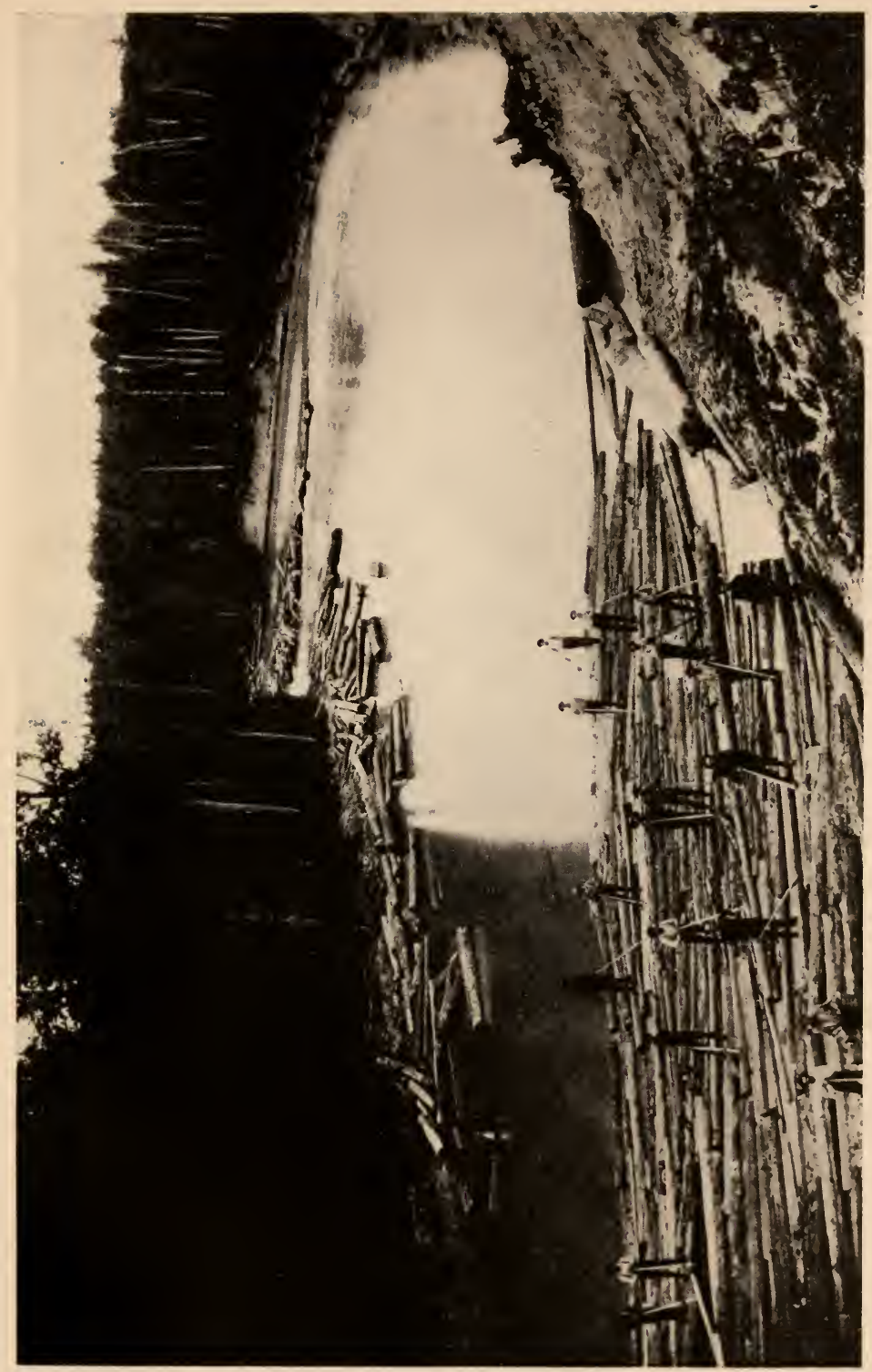

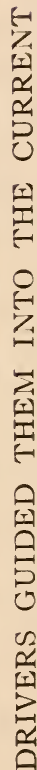



dark head a little closer to the maples, whispering, "Sleep sweetly through the winter, and when the spring awakes you and hangs your boughs with coral, think of me!"

"But you will talk to us, will you not, when the spring returns?" asked the maples, who had learned to love Picea and no more made fun of her old green dress.

But Picea answered, "Listen!"

"I hear only the wind and the river," replied a maple tree.

"Listen!" repeated the spruce; and as the maples were quiet, listening, one by one they fell asleep.

But Picea was awake, listening to the call of the river.

At last one night, while the old spruce was dreaming, Picea answered that far call from the valley.

"Whom are you calling?" she asked.

And the river answered, "You!" 


\section{IV.-THE Book}

As a tree feels the approach of a cold winter and thickens the walls of its buds, so Picea knew that her days in the forest were numbered. And one day the axman came, and her tall spire, pointing so long to the stars, fell crashing to earth.

Touching the old spruce in her fall, Picea called, "Mother, good-bye!"

And the old tree answered, "My daughter, may all go well with you out in the world!"

Picea came heavily down upon the pretty little spruce tree. "I did not mean to harm you," she said tenderly. "I had hoped that you would take my place in the forest."

Shorn of boughs, her trunk was measured into smaller lengths, and skidded, with many. others, down to the river.

"I heard you call, and I have come," she said faintly to the river. "Oh, your touch is cold and chills my heart! Let me rest here awhile; I am not ready for the dance."

"Rest!" whispered the river. "Lie here by. 


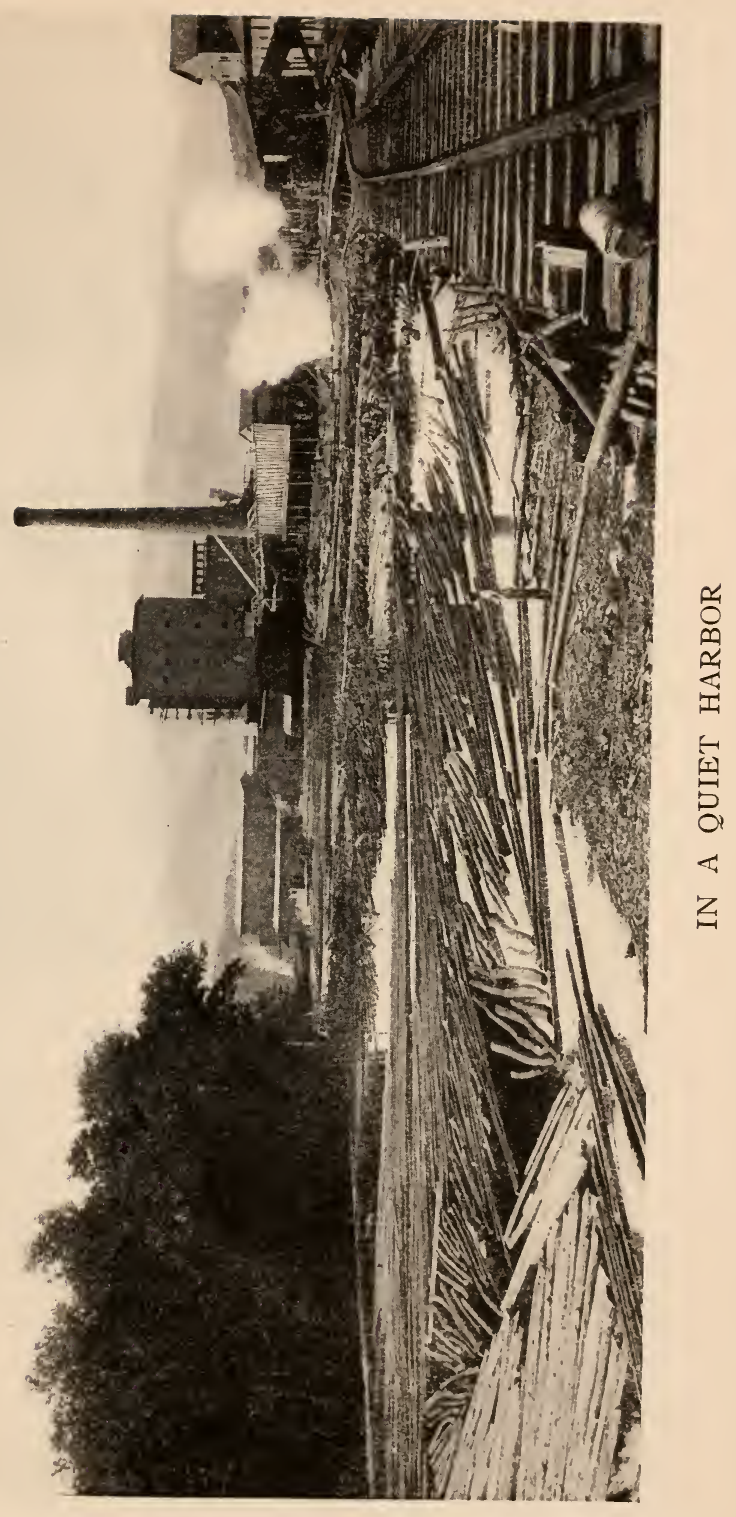



my bank in the shadow of your home and sleep through the winter, dreaming that still the wind plays over your boughs and sings to you through the long winter night."

"I cannot dream that the wind caresses me," sighed Picea, "for your touch is cold, colder than the north wind!"

"Let my song weave through your dreams," murmured the river, "until it is like the lullaby of the wind when you swung in your conecradle on the spruce tree bough. When the spring comes, I will wake you and bear you away."

Picea lay silent, listening to the song of the river. The dark, cold night came; but the same stars as of old looked down upon her, the same stars with the same message. And so she slept, dreaming that once more she stood upon the mountain side, binding her forehead with boughs of green and lifting her taper fingers toward the stars.

At last the winter sleep was over, for spring had returned to the forest. Slowly the river rose, lifting Picea and her sylvan friends. 
Drivers guided them into the current. There was the lulling motion of moving water; then the mountains went slipping by and the forest faded into the past, and they floated far, far down the changing valley, out into that great world which Picea was now to know.

In a quiet harbor, the forest pilgrims found their rest. A mill rose before them like a castle; but to Picea it was the gateway into the world, which she was to enter, dressed in bark, and come forth in a garment of snow, clothed like a bride.

One day the poet opened a book. Picea remembered the touch of that hand. His look drifted over pages white like the dogwood in bloom, yet lingered upon one-the least of all the poems; and he seemed once more upon the mountain side, listening to the song of the spruce tree:

Formed and fashioned like a tree, Shade I am and shield to thee, How content, through sun, through rain, In the forest to remain! 


\section{FOREST LEAVES}

But when echoes thy far call, Let a change my lot befall -

Garment of the tree I doff, Cast my crown of branches off,

Hasten from my sylvan home, Thee to find, though far to roam, In new service unto thee, Still to serve humanity:

Bear thy message to the world On my wings of white unfurledBear thy heart's own message then To the hearts of other men! 



\section{THE MERRY GREENWOOD}





\section{THE MERRY GREENWOOD}

"Old nurses do not tell children about the grass, but about the fairies that dance on the grass; and the old Greeks could not see the trees for the dryads." -Gilbert K. Chesterton.

\section{I.-THE WoOd-NYMPH}

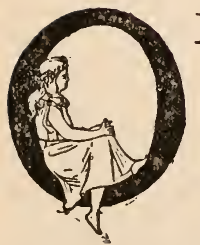

NCE upon a time there was a forest that stretched for many miles over mountain, valley, and plain. the trees bound the soil with the strong chain of their interwoven roots, and with their interlacing branches formed a shelter for the wild bird, a haunt for the deer, and a shade for the sons of earth.

And there were other inhabitants of the forest-little wood-nymphs who dwelt within the trees, like good thoughts in kindly hearts. The clear-eyed Indian must have seen them-for 
were there not spirits of air and forest and water? But this was many years ago.

One day, as the wood-nymph of the birch tree guided the Indian's bark canoe, a waternymph brought news :

"I have seen a canoe, made of much wood, at the mouth of the river; and the faces I saw were the color of shells."

"The canoe has wings, and I blew it across the sea," cried a sylph of the air. "The Pale Face has come to make a home for himself and his children. Some day he will possess the forest and the rivers."

Did she whisper warnings to the Indian in his canoe? For he pricked his ears like a startled deer, scenting an enemy who would sweep away the Red Man and the forest that he loved.

Two hundred rings and more had circled on old oak tree since the landing of the big canoe, when a pioneer stooped and drank from the spring that bubbled among its roots. Then, shouldering his axe, he followed the stream 

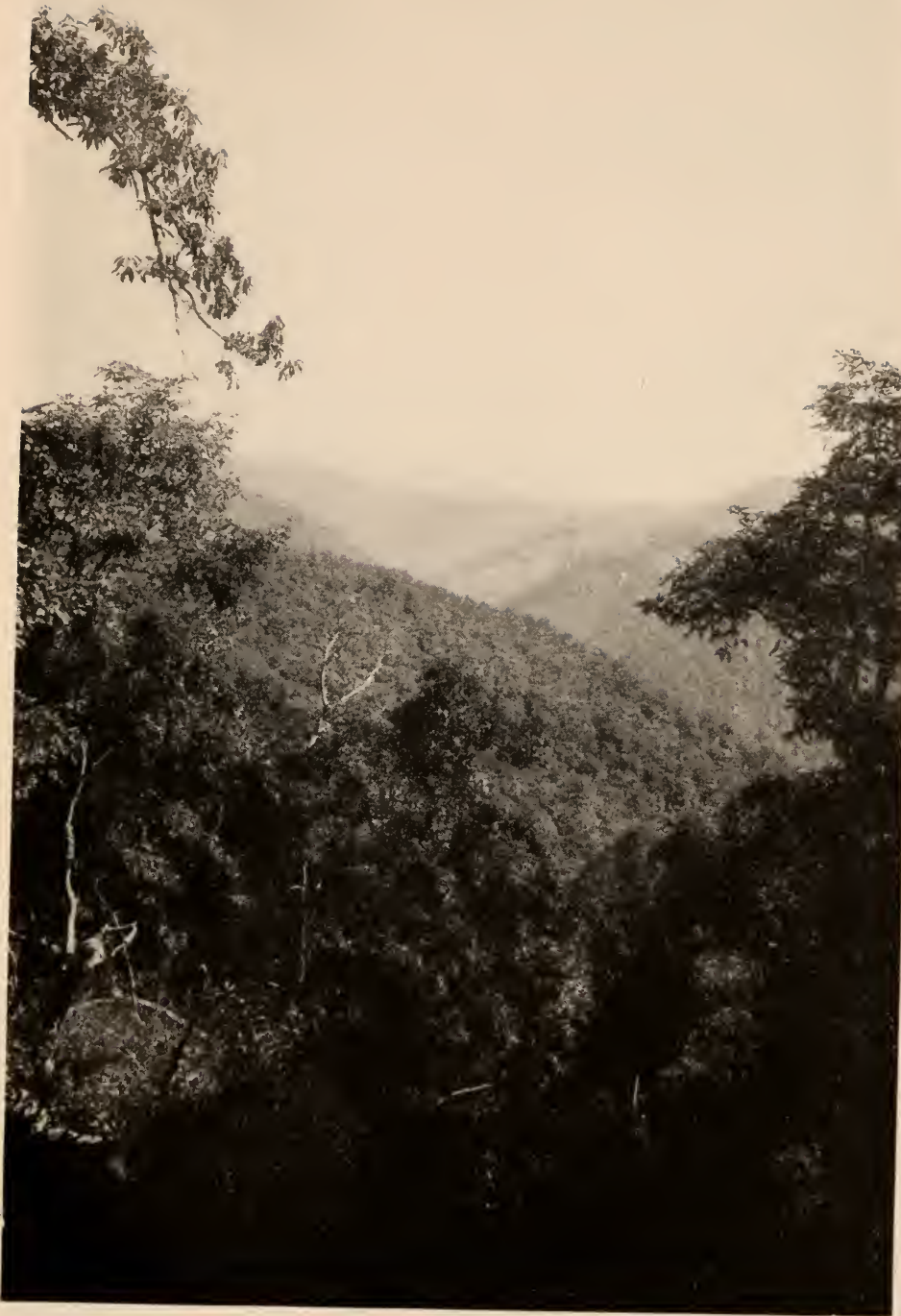

ONCE UPON A TIME THERE WAS A FOREST 

through the forest. In a favored spot he cut down a tree; and where the tree fell, a cabin grew.

To this cabin the pioneer brought his wife; and the wood-nymphs whose trees they had taken for house and fire came, silent and unseen, to their bright hearth. When there were three in the home, they gathered around the rude cradle, and the child caught their whispers and smiled.

As the child grew older, he used to follow his father into the forest. Here day after day. the restless axe was swung, to give them a little ground for corn and wheat. But sometimes the boy would run from the sound of the noisy axe and wander up the stream. His favorite spot was under the oak, where he would often sit for hours, gazing down into the spring.

As little Josiah sat here one day, longing for someone to play with, suddenly a pair of soft hands were clapped over his eyes: "Guess who?"

"I saw you in the spring!" And before the 
nymph even thought of her tree, he turned and kissed her.

"Why have you never come to play with me before?"

She sprang up, laughing. "Come, let us play now, and make up for lost time."

So they played all day long in the forest; and she showed him in which trees his top and hoop, his bat and sled, his box and basket grew. "Every day," said she, "you will want many, many things that grow in trees."

And true enough, he found that house and hearth-fire, the fence around the clearing, the chair and the table, his mother's spindle and the oxen yoke, the wagon for the road and the bridge and the boat for the river, all had grown in the forest.

And then he became more and more interested in the things that came from the forest, until he almost forgot the forest itself. As for the little wood-nymph, he began to doubt whether she really did live within the oakor did she not mean some log-cabin on the mountain? 
"Nay, nay," she laughed, "I am the guardian of this spring; and as long as the oak tree stands, it is my home."

"Then as long as I live," he exclaimed, "your oak shall stand, though "a thousand fall at thy side!",

"Aye, the thousands are falling," she said sadly. "Man needs much wood; but the rivers, too, need trees."

Josiah pondered upon her words, and one day he asked her what they meant.

"Under the shade of this forest," she answered, "and through the great sponge of its leaf-mold and the root-bound earth beneath, the rain soaks slowly, slowly down, to trickle out at last in tiny springs. So leave the trees upon the mountain side, for the forest is the river's friend."

"As the forest protects the streams," he cried, "so I will protect the forest!"

However, he was now learning things out of books that told him nothing about little woodnymphs who guarded springs; and in the passing years, he had no time to think of the forest 
or the spring or of her who watched beside it. All his thoughts were for the law of the world, and all beautiful laws that were higher, and all inner meaning that lies beyond the material expression of things, faded from his mind.

As his inner ear closed more and more, his outer ear caught louder the call of the world, and one day he packed the old family carpetbag and started for the city.

Before Josiah left the clearing, ho happened to think of the spring, in the water of which he would drink to his success, and there he remembered the wood-nymph.

"Did you call me?"

"No, I did not call you," he confessed.

"Ah, I heard your thought and came, before the world should teach you to forget."

"But I will not forget," he cried, "and every year you may look for me with the laurel."

"Nay, you will forget the forest, you will forget the spring, and her who watches by its side. The world will tell you naught of little nymphs who live within the trees; and by-and- 


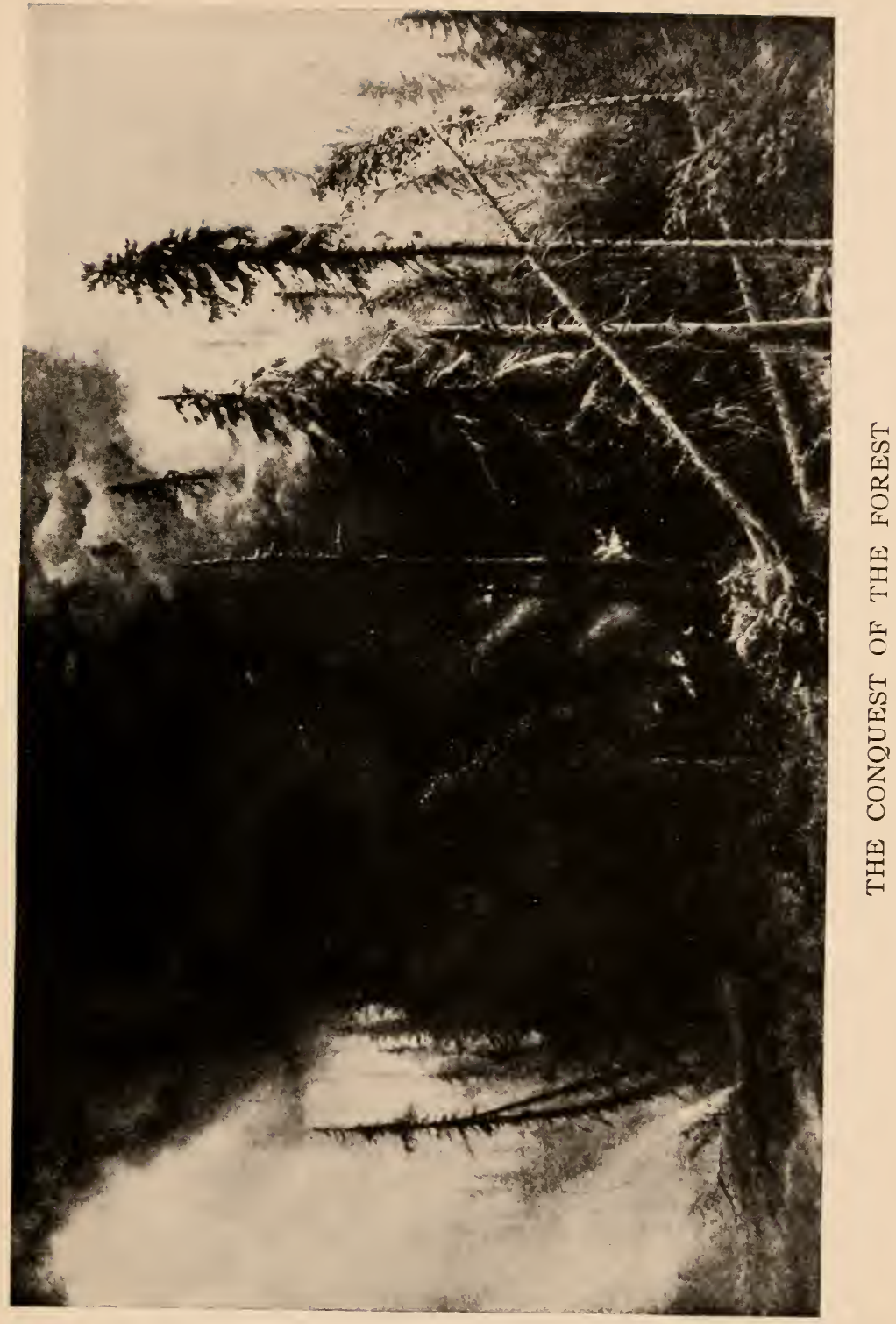





\section{THE MERRY GREENWOOD 123}

by you will not be able to see one, even though you try-worse still, you will not care. Only children are wise enough to know."

"Then give me the heart of a child, for you I will never forget, nor my promise to save the forest. I swear it on the oak: I will be true."

"Nay, do not swear it on the oak," said she, "for the oak will fall. Give me your hand across the spring."

So he bared his head and knelt among the ferns-but he found himself alone-alone in the vast stillness of the forest.

"You were only a dream after all!" he breathed, though her eyes were blue in the shadow.

Then he shook off the spell of the beautiful solitude.

"Away with dreams," laughed he, "for life is real!"

And gripping his carpetbag, he strode down the path beside the stream, out into the world, where he became a great man.

The laurel blossomed around the spring, 
wherever the ferns made room. The laurel faded and the snow fell and made a fairy forest all around, with only the little dark well of water to break the pallor. Fifty Mays the laurel bloomed, fifty winters the white snow. fell. The wood-nymph waited beside the spring, waited and watched for him.

\section{II.-The Fall of the OAK}

While the wood-nymph waited by the spring, settlers were building homes beyond the mountains. Every day the field grew larger and the forest smaller. Even there she could hear the echo of the axe among the hills.

Then one day a settler, passing by, stopped to drink at the spring.

"Have you come to save the forest?" she asked of him.

"Why, there is timber for all," he exclaimed, "and trees for bonfires."

" 'Waste not, want not!" " was her warning; but he went on his way, clearing the ground to farm. 


\section{THE MERRY GREENWOOD}

Next a lumberman came by, carrying his axe and his saw.

"Have you come to save the forest?" she inquired.

"The world wants wood," he replied, "and there is plenty." And he pushed on his way, sweeping the hills of trees.

"Waste not, want not!'" chorused the wood-nymphs; but the bark of the axe and the snarl of the saw were so loud that he could not hear, and taking only one log from each tree, he threw the rest away.

" "Waste not, want not!'" they repeated; but the slash that he left behind, dried in the sun. Here a careless spark found its home, and fire went roaring over the mountain.

And so the forest was conquered. The hills lost their beauty and the ground its bond of roots; the deer lost its covert, the wild bird its shelter, and little rills laughed no more among the mountains.

The spring rains fell and snow melted on the peaks. Where there were no trees to hold the water back, the swollen streams rolled brawl- 
ing to the rivers of the valley, and floods overspread the land.

The water-nymphs lifted their eyes to the hills; but the roots that bound the earth, the boughs that shaded the moist earth, were gone. There was no forest well to hold the rain.

Then the wood-nymph of the oak tree, hearing their plaint, strapped on her sandals of bark.

"I will go forth and seek one who will save the forest."

With her green mantle on her arm, she paused under the shadow of the oak: the bite of the axe-how near!

That same night, in the City of the World, three hundred sat at long tables in a banquet hall, but no one noticed the window where two bright eyes kept watch. There were sparkling glasses and sparkling speeches; someone arose amid applause. The little figure at the window tiptoed to see, but only the voice of one grown old, yet still very much alive, reached her straining ear. 


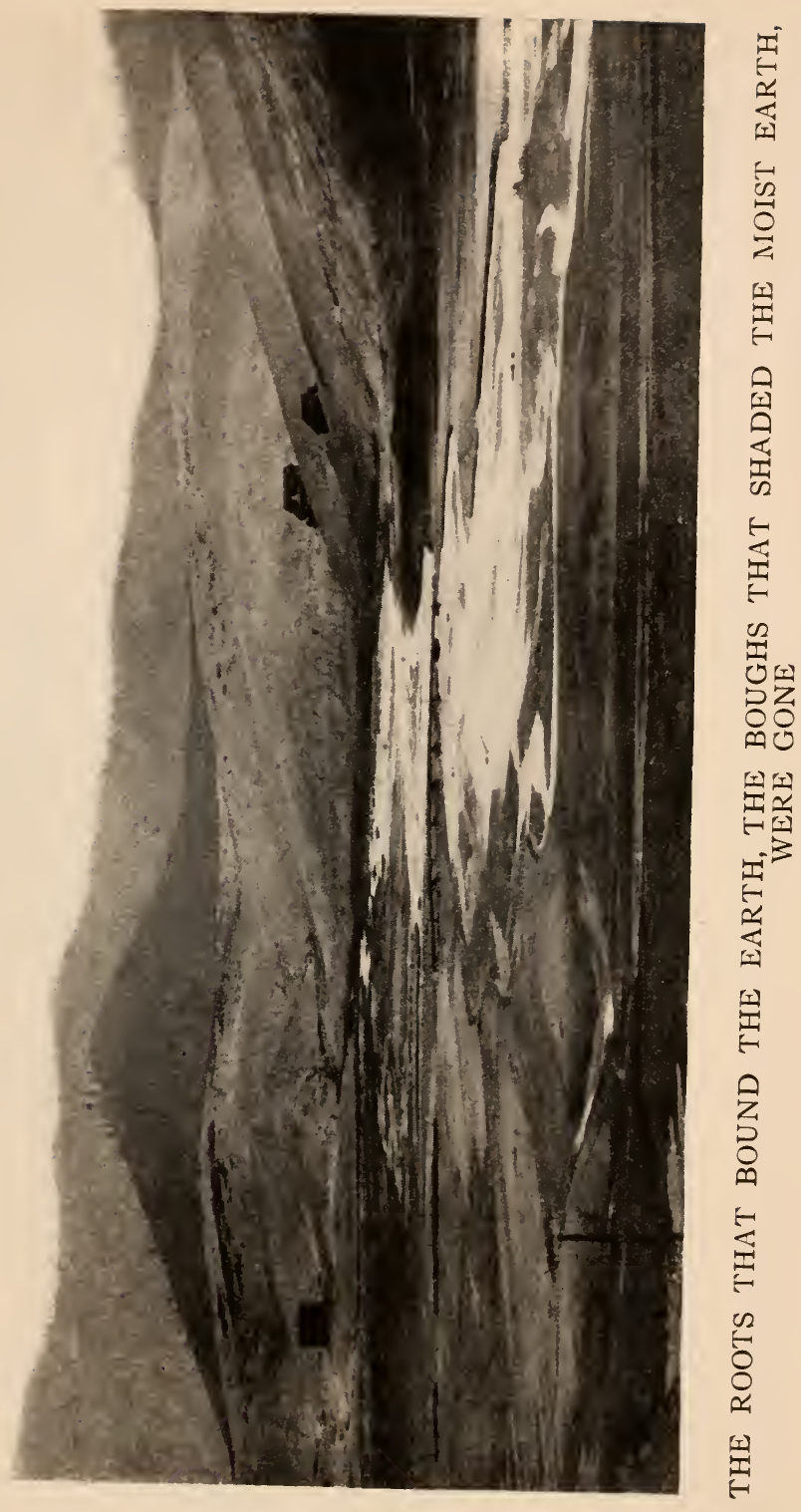





\section{THE MERRY GREENWOOD 127}

Laughingly he greeted the three hundredfor the shadow of the vine was upon him, and upon all the three hundred.

"Gentlemen," said he, "our first enemy was the forest. When the Pale Face came to make his home, trees stood guard along the shore and fortified the hills. The forest possessed the land. Out of that wilderness, we have builded a Nation. The trees made room for the cabin. The forest gave place to the cornpatch. You ask, what will become of the world without any trees? What would have become of us with so many? Shall we freeze now, that the future may be warm? When the heat of the sun gives out, 'what will poor Robin do then?'

"Friends, the forest is ours, so long as it lasts. Let us keep on cutting down trees, and never think of to-morrow. With Whittier, we will gladly say:

" 'I, grateful, take the good I find, The best of now and here!'

"Gentlemen, good-night!" 
Before the speaker sat down amid applause and laughter, the one at the window, tilting on her toes, eaught sight of him; it was Josiah.

Some time later, as he left the marble portal, he noticed there a little maid in green. The hour was so late, or rather so early, that he wondered at her, and why she looked so sad.

"My home is in danger," she answered him. "My dear child, let me help you."

"Then follow me."

Josiah grew breathless, so fast did she pilot him through city streets to country. Was he dreaming? Should he pinch his arm to see?

They skimmed over barren hills, robbed of their trees by axe and fire; they passed deserted upland farms with their soil washed away by rain, and lowland farms destroyed by floods. Josiah spoke:

"The Kansas poet wrote of 'walls of corn,' a good idea."

She nodded wisely. "And what about our 'walls of trees'?"

"'Walls of trees'?" he repeated. "Yes, there were 'walls of trees' along our coasts and 
by the Lakes-but we are breaking down our "walls of trees." "

"Come hither, and answer the question, 'Does it pay?'"

She led him down to the river, flowing brown between bare banks. Something was moving on the surface, white like a waterlily. Josiah sprang forward:

"Pick her up tenderly, Handle with eare___"

"I'm not glass," said the water-nymph, lifting her face above the flood.

"Pardon me," said he. "Can I be of any assistance? Will you join us here, and dry your wet garments in the moonlight?"

"This is my home," replied the waternymph.

"A damp place," commented Josiah; "a trifle muddy, too."

"You know why it is so," she complained; "where you have taken the trees from the hills, the soil washes down into the streams."

"Madam, I will immediately get Congress 
to appropriate a few millions and make your damp little home all clean-dredge it out, you know; sort of house clean it."

"I wish you would do so every year," she said fretfully, shaking the clinging sand from her hair, "or keep the hills out of the river, where they don't belong."

"That is a big proposition," returned Josiah. "However, we might plant some trees upon the hills, and keep them there. That would be cheaper in the end. I should certainly like to make you ladies comfortable."

"I have been trying to turn your mill wheels, but the streams are inconstant, for the springs dry up. I want clean water for your cities. I try to float your ships, but the silt chokes the channels."

" 'Little drops of water,

Little grains of sand," "'

repeated Josiah thoughtfully. "That's just it!" she cried.

A sylph fluttered from the sky. "The forest draws the rain." 


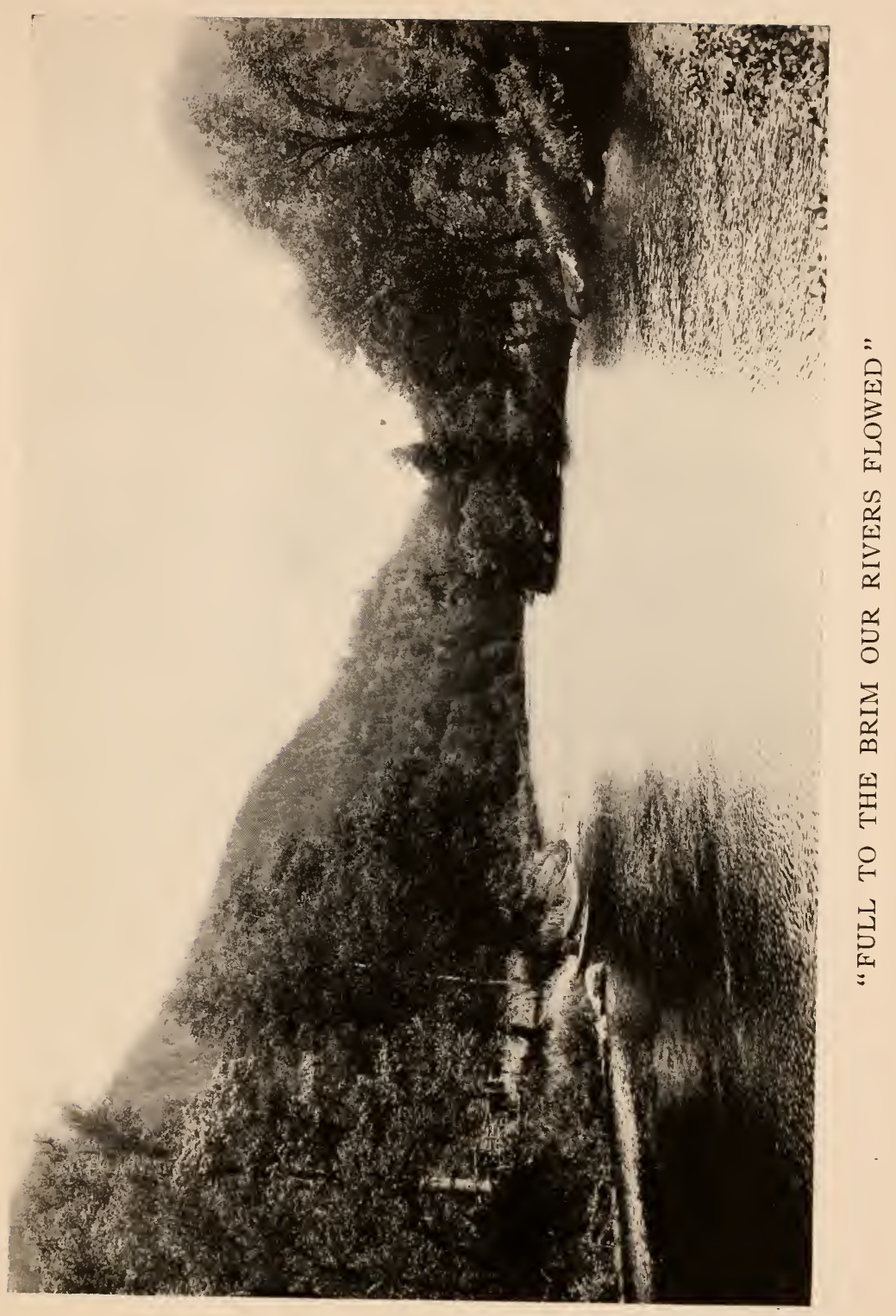



"And stores the rain," said the one in green.

"And metes it out pure to the springs," said the water-nymph, "that the streams may be clear and constant."

And then they talked to him, and he was glad to listen; for they were three very charming maidens, earnest and sweet in their endeavor to show that this earth should be made a good abiding place for all.

Being old, Josiah got a little rheumatic sitting upon the ground; and as Miss Butterfly spread her wings to the starting breeze and Miss Waterlily floated out upon the tide, he arose stiffly.

"My dear young ladies," he conceded at last, "since I was young, things have changed; there are more people and fewer trees; and it will be wiser to treat the forest as a friend rather than as an enemy. We must be more careful about the cutting. Yes, yes, it will pay; and I wish I had the three hundred before me now, I would put another end to my speech. To show a man his interest is doing more than making laws. I would show that 
we were misusing a good friend, killing off the forest. And I would add the words of Bryant, our poet:

" 'Before these fields were shorn and tilled, Full to the brim our rivers flowed;

The melody of waters filled The fresh and boundless woods; And torrents dashed, and rivulets played, And fountains sported in the shade.'

\section{"Ladies, good-night!"}

Josiah bowed. Butterfly fluttered off. Waterlily drifted down the stream. He and the one in green were left alone.

"You told me your home was in danger," he said. "I had well nigh forgotten my mission."

"You are prone to forget," she reproached him. "Follow me."

She led him toward the mountains. The scene grew familiar. He looked down at the half-hidden path, once a sandy road in the forest, now hardly a trail through brush.

"Is this the road I remember?" he asked. "Nigh sixty years ago I used to drive here under the trees, past little springs hidden among ferns, great wavy ferns, drive for miles 


\section{THE MERRY GREENWOOD}

that seemed short to the little white meetinghouse that stood here, with the crystal branch in front, singing over its stones. If we could sing over hard places the way a brook does, wouldn't it make it pleasant along the way?"

She nodded and tripped along, toward the forest, to a little spring under an oak tree. Over the far mountain the dawn had kissed a wandering cloud to a rosy hue, and it now revealed the face of her who stood beside the spring. What he had thought a green mantle were twining oak leaves, and from their shadow her eyes looked forth into his soul.

"Forgive me!" he cried. "I forgot youforgot your voice in the sounds of the world, forgot your eyes in the sights of the world, forgot my promise and our tryst!"

She smiled-a little mockingly.

"I will redeem my promise. I will serve you, as you serve mankind. I will protect the forest and save your tree. It is not too late."

But her face was lost in shadow as she slipped back into her tree, with the echo, "Too late, too late!" 
As Josiah made his slow way down the stream, he met a woodchopper entering the forest; and though he cried, " $\mathrm{O}$ woodsman, spare that tree!" "the man, unheeding, passed. Soon the early morning stillness was broken by the sound of a quick axe, followed by the crash of a falling tree.

\section{III.-THE KING OF THE Forest}

One summer morning a bugle call awoke the echoes among the mountains, and a young man came merrily over the hills. As he went, he meted out land for farm and for forest, that Nature might best serve Man. At sight of a pretty maid in the wood he swung off his big gray hat and smiled.

"Pardon me; I thought I was alone-alone but for the wild things, the trees, and-God."

"I live here in the forest," she replied.

"I envy you," he said.

"Then if you love the trees, why that hatchet in your hand?"

"You don't think that I could cut down a 


\section{THE MERRY GREENWOOD 135}

great big tree with this little hatchet?" His laugh rang merrily through the silent wood. "Madam, this forest has been given into my keeping, to preserve, not to destroy, that it may be a blessing now and in time to come."

As he spoke, he chipped the bark of an old tree with a heavy shade.

"Who woke me?" And a wood-nymph ran lightly from the tree.

"I'm sorry, Miss," replied the young man, abashed; "I didn't know you were sleeping in the tree. I was just marking it to be cut down, for it is keeping these younger trees from growing."

"Yes, it is time for my home to go, for here it is worse than useless."

As he chipped a second tree, another nymph awoke.

"Who cut into my tree?" she asked sharply.

"I did it with my little hatchet," he answered frankly, "for it is crowding better trees. But I am right sorry to disturb all you girls. I didn't know you were having a picnic in the woods." 
"The trees are our homes," they replied.

A light dawned in the young man's face.

"I thought Uncle Josiah was dreaming," he murmured. "Yes, yes, there are woodnymphs. I remember now the one who used to rock my oaken cradle and sing me songs of the beautiful forest that God had given to Man. How one forgets as one grows up!"

He paused before a large. fine oak loath to chip its bark.

"Hush, woodpecker!" cried a voice within. "I was sleeping, dreaming that my oak had been made into handsome furniture to gladden a good man's home."

"Such a tree would make a fine quartersawed oak set," replied the young man. "I wish I had it."

And he tapped upon a tall chestnut.

"Who knocked upon my door?"

"I'm awful sorry, Miss, but I must ask for your pagoda."

"Are you a forester?" she asked.

"A server of the forest," he replied.

"Then take my home." 


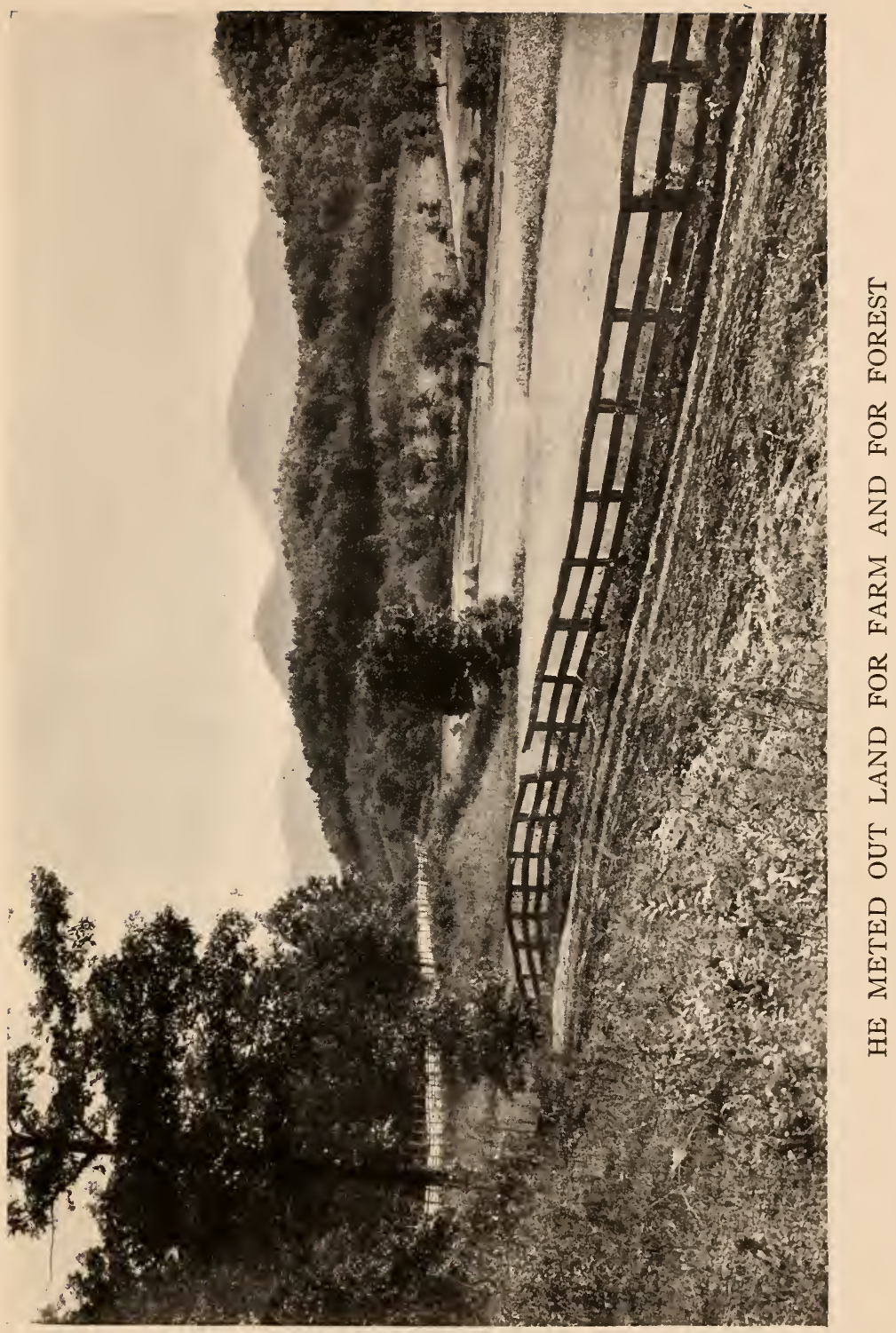



"And mine!"

"And mine!"

The young man looked thoughtfully over the trees, planning a new forest out of the old. Yet suppose a fire should burn the forest and the dream?

"When your trees are cut," said he, "a lot of slash won't be left lying around, ready for a big bonfire. No, the branches, cut off and given back to Mother Earth, will rot and enrich the soil, and so return to Life. And nothing will be wasted. Don't you know that our Teacher said, "Gather up the fragments that remain, that nothing be lost?' It is good to apply this to the great, beautiful wealth of forest which we find here for our use. That's common sense. I'm a practical man, and want to keep this old earth of ours in good working trim, that's all."

"Hail!" cried the wood-nymphs, laughingly clasping hands and circling around him, calling him king of the forest.

Of course, the forester felt a little shy, though after all he was willing to join hands 
with them and play even "Ring-around-arosy."

As the song of the dancers died away, a nymph came running up: "The queen says, 'Bring hither the young man with the hatchet." ",

They led him, laughing, through the woodland way, to what ordinary eyes would call a pile of slash, but which he perceived to be a rustic throne, made from the loving arms of the old oak tree, mantled with moss and ivy, and holding her who had been chosen queen of the wood-nymphs because she had saved the forest.

As the forester approached, the queen, seeing the hatchet, frowned. Thrice he bowed, and thrice he kissed her hand before she spoke.

"What have you to say, woodchopper?"

"But, Madam, that is not my name."

"A lumberman, then?"

"Not so."

"Then, friend, what is your name?"

" 'Friend,' that is right: I am a forester." 
"So you have a mission in the forest?"

"Madam," he replied, "it is written, "The earth is the Lord's, and the fullness thereof.' The earth, and the fullness of the earth, are for all. The forest is for all."

His words dispelled her frown.

"I have waited long for you," she said, "but I have not waited in vain."

"Dear queen," said he, "in serving you, I serve mankind."

"And so we bury the hatchet."

But the forester looked alarmed as he replied, "O Madam, this is a useful little tomahawk, meant to mark those trees which the forest will give to Man."

"Aye, but be sure that the forest yearly gives no more than it yearly grows."

"And the forest will live forever!" cried the nymphs.

"Then long reign the queen of the woodnymphs!"

"And long rule the king of the forest!"

"The day departs," he said at last, "and I must follow; but I will return with the snow 
and my axe shall do your bidding, my fairy queen. For I will not forget my promise-I will be true: I will serve you to the end of my. days."

"Then give me your hand over running water; remember, only he who is true, must vow."

So he knelt in the ferns beside the stream and vowed over running water. But when he arose, the queen was gone, the nymphs were flown-a hundred years had rolled away: he saw the forest of the future, crowning the hills from sea to sea.

Then this, too, vanished. He stood in the limitless Present, alone with the trees. 


\section{THE FRUIT OF}

\section{THE CHRISTMAS TREE}





\section{THE FRUIT OF THE CHRISTMAS TREE}

Not cone, nor candle, nor gifts, nor golden star.

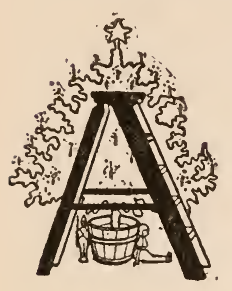

LITTLE balsam-fir tree grew in a forest, in a pleasant opening like a nursery-room, where other baby evergreens were blinking in the sunlight, with only here and there a mamma-tree holding her parasol over their heads. While the older trees exchanged ideas about the weather and other important topics, the little trees sat in their cozy spot, playing they were big trees, and as they grew taller, trying to wear cones like their elders. They all wore dresses of the real forest color, green, and the same little frock did for summer and winter.

"It seems so odd," said a balsam-fir to a birch tree, "that you should take off your dress as soon as cold weather comes."

"And I have often been surprised," replied 
the birch tree, "that you should wear fir all summer."

"However," put in the cedar tree, "you know that cedar keeps away moths."

"And if that doesn't mend matters," cried the pine tree, sharp of wit, "then please try, my needles!"

"Don't let us talk of clothes," begged the little balsam-fir; "let us play at being grown up, and talk of the things that we'll do then."

"Perhaps they won't leave us here to grow up," said the spruce tree. "As we grow bigger, we'll crowd one another and stand in each other's light."'

"Then let us be happy while we may," breathed the balsam-fir, "and love one another."

"May you never be taken from us, Cho-kohtung!" exclaimed the pine tree.

Cho-koh-tung smiled at the old Indian name, which means the balsam "blisters" on her bark.

While the little trees were playing at being grown up and talking of the great things that they would do when as tall as the mamma-trees 


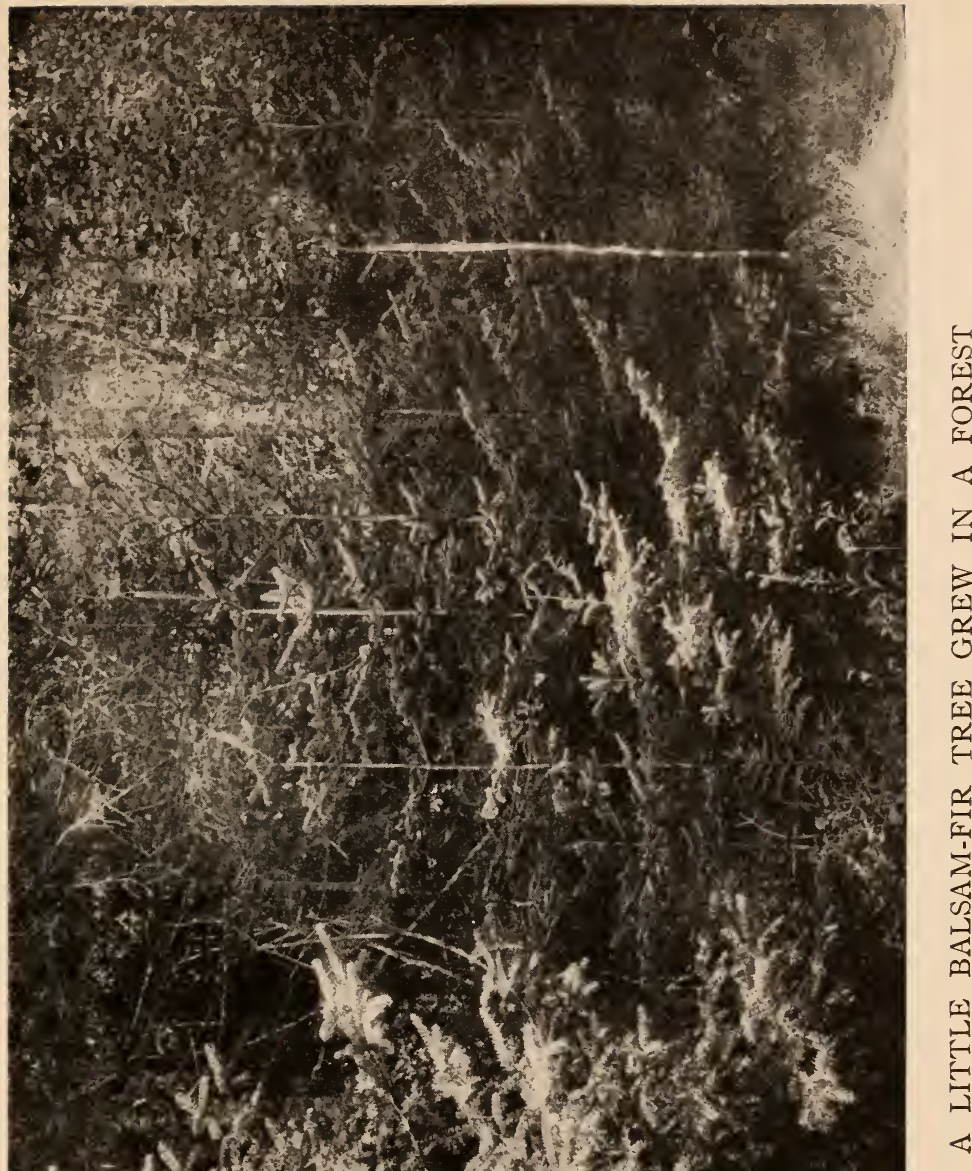



holding parasols over their heads, real children, who had grown up between brick walls on a paved street, came trooping into their nursery-room.

"When I am a man," cried Alec, the oldest, "I'll be a forester and work in the woods!"

"And I," said Archie, "I am going to build houses out of wood."

"I am going to live in a tree!" shouted little Ray, and all laughed.

"What are you going to do, Emily?" asked Archie of their sister.

"I should like to take poor city children into the forest, that they might be as happy as I am now," Emily replied. "See, Alec, what a beautiful tree, so like a cone! I think it must have grown here just to make me glad."

And she sat down beside the little balsamfir while her brothers scampered about like squirrels.

"I have seen trees that looked like you, every Christmas I have seen them," she said to Cho-koh-tung, for it seemed as if she had found a little woodland friend in the great 
forest. "Those trees grew in painted tubs and stood in warm rooms with tinsel and tapers on their branches. They were Christmas trees." "What is a Christmas tree? And are tinsel and tapers the fruit of a Christmas tree?" asked the balsam-fir; but little Emily only inhaled her fragrant breath.

"Now I know how Christmas trees look before they come to the city," Emily continued. "They are all steeped in sunshine and full of the sweet, smelly breath of the woods, and I think that is how they are able to make us so happy-more happy even than the beautiful gifts on their branches make us."

" "Gifts?" repeated the balsam-fir. "Are gifts the fruit of a Christmas tree?"

While Cho-koh-tung was wondering what kind of a tree a Christmas tree was, Alec came shouting around the pine tree. "Here is a real Christmas tree. See, Sister, it has green candles all over it."

Emily looked at the soft new tips of the pine tree, erect like tapers.

"Yes, this must be one, too," she said. 
"What a gay little place! All the pretty evergreen trees keep Christmas here together, though some of the child-trees come to town to make us glad at Christmas time."

"Dear one, would it make you glad should I leave my forest home and come to you at Christmas time?" asked Cho-koh-tung. "Yet tell me, what is Christmas time?"

Did Emily understand? For she smiled and said, "Christmas time means happy time, and the giving of gifts!"

And then the merry band of children went laughing into the forest.

"They talked of what they would do when they grew up," said the pine tree. "As for myself, I expect to be changed into something useful to Man."

"As the sunshine blesses us now," said Chokoh-tung, "so a way will come whereby we in turn may bless with the sunbeams stored away, transformed into the sunlight of joy. I hope it may be my mission to be something that children love. That will be better than living my own life in the forest." 
"A child loves her little chair," said the pine tree, "yet never thinks of the oak that took a century to grow the wood."

"If I could make children glad," replied Cho-koh-tung, "that would be my. reward."

"Then be happy," whispered the sunshine, "for the children who come to the forest see you and rejoice in your beauty."

The little balsam-fir looked up gladly to the caress of the sunlight. "I am happy, but the habit of playing at being grown up leads me to plan for the time when youth is gone and the beauty of youth."

" 'Rejoice in the days of thy youth!' "repeated the sunshine.

So Cho-kuh-tung ceased thinking of the future and was happy in each passing hour, trying to grow cones upon her branches like the tall young balsam-fir near by.

"Christmas time means happy time, and the giving of gifts," she mused; "I wonder if I can grow pretty cones to give to Emily when she returns." 
"Have you nothing else to give?" asked the sunshine.

The little balsam-fir did not reply; she was thinking, how sweet were sunlight and wind and forest odors, grass and moss and flowers, bird and bee and butterfly; how sweet to live!

One day in December men entered the nursery-room with axes in their hands.

As they were passing, Cho-koh-tung called, "Take me!"

"Are you anxious to leave us?" asked the spruce tree. "Your life has just begun. Life is sweet!"

"Already I am crowding my little sister on the other side," answered Cho-koh-tung. "Besides, it is the child-trees that go to town at Christmas time."

"Cho-koh-tung is going to town!" whispered the trees excitedly.

"Will you bring me something from town?" cried her little sister eagerly.

"When you come back," asked the cedar tree, "will you tell us all about the wonderful things you have seen?" 
Cho-koh-tung smiled a little, knowing she would never return.

Then the men cut down the balsam-fir, wrapped her ruffled skirts with twine, and bound her with several other evergreen trees of her own height that they had taken from the forest. These were piled on a hay-rack and hauled away and loaded upon a platform car. After a swift, astonishing ride, they found themselves in a place where there were hard pavements instead of grass and moss, and tall buildings instead of trees.

The sounds of the city frightened the little trees. They clung close together and whispered of home, until one by one they were taken away.

At last it was Cho-koh-tung's turn. She was hoisted into a wagon and driven to a brick house and set up in a tub in a darkened room.

"Will it always be night?" she asked, but no one made reply.

She now observed upon the walls festoons of hemlock and holly wreaths, though these reminders of the forest only made her more 
homesick. She began to talk to the chairs, which seemed quite at ease, and asked them why she was kept a prisoner.

"Wait and see," answered the armchair.

So the little balsam-fir was patient.

By-and-by, when it really was night, two people entered the room, and the man lit three great stars hanging from the ceiling. Chokoh-tung could now see that the trees which had been made into furniture looked very comfortable and at home.

"I hope that I, too, may become part of this pleasant home," she thought wistfully. "Perhaps after awhile they will let the children come to me, when I will tell them stories of the forest. I may have a long and happy life here."

She stood like a statue in her tub, very much interested in what the people were doing. They brought in boxes and baskets and a stepladder, and the man fastened a great gold star to her topmost branch.

"Thank you," said the little balsam-fir. "I am sure it looks very pretty. How I wish the 
children could see me now! I wonder, oh, I wonder-yes, the wish that led me from my forest home is to be realized: I am to be a Christmas tree!"

She was so overjoyed at the thought that the star trembled. "There must be a draft in the room," said the mother.

Cho-koh-tung rejoiced in the silver paper icicles, the glittering balls, the festoons of tinsel, the tapers, the dancing dolls, and the dolls with gilded wings that fluttered to her branches. In the tub at her feet they put green moss and a whole barnyard of wooden animals, and all around were placed the blessed toys.

"The children will gather around me to receive their gifts," she thought; "yet sweetest of all, I shall give them myself !"

The mother and father stood off and surveyed the tree, smiled at each other, glanced upward where four cherubs were sleeping, turned out the stars that hung from the ceiling, and tiptoed from the room.

But, so great was her anticipation, the little balsam-fir could not sleep. With all her gay, 
festooning, she wished to dance, as when she used to toss her ruffled skirts on windy days and show their silvery lining.

"You better stand still, little balsam, and be philosophical, like Diogenes of old," warned the painted tub.

"Who was Diogenes?" asked the balsamfir.

"Oh, he was like you, and lived in a tub," laughed the book under the tree. "I know all about such people. Then there were three men in a tub. But before we proceed further, I move we have a little light on the subject."

"Dear me, I cannot find my match!" cried a taper.

"No, I have struck," declared a pine match quite black in the face, so the window shades rolled up and let in the light from the streetlamp.

"Tub," asked the balsam-fir, "where did you live before you came here?"

"In a store," promptly replied the tub.

"Yes, but before that?"

"I was a cypress tree and grew in the 
water," answered the tub, "and I think that is how I came to be a tub."

"I sailed right out of a poplar tree," said the toy ship.

"And I was made in America!" shouted a wooden soldier. "Forward, right, march!"

"Look out, or I'll run over you!" cried the little express-wagon. "I'm Old Hickory, you know. Miss Dolly, won't you take a drive?"

"Thank you, but I prefer to ride my hobby," replied the doll, mounting the maple hobbyhorse. "A little exercise will do me good."

"You needn't put on such airs because you are bisque and kid," remarked the black walnut writing-box.

"Sawdust!" laughed the set of tools with hornbeam handles.

"Yes, I saw dust," added the saw, as the hobby went prancing by.

"Cedar pun?" yelled the pencil.

"Order!" rapped the hammer.

"I am always in order," declared the desk. "My home," it continued, reminiscently, "was in 'the spreading chestnut tree." 
"And I," said a work-basket, "was the withes of a willow."

"We were part of a pretty birch tree," explained the spools in the basket.

"Whoever would dream that I was once a spruce tree ?" inquired the book. "Little balsam, of all my forest friends, you alone remain unchanged."

"Our good old forest days are over," replied Cho-koh-tung, "but new service has begunto gladden the hearts of children. Little will the children know of the tree-lives given up for their sake, yet a sacrifice is not a sacrifice that brings a greater joy."

"Love should inspire service," responded the book, "and service be the keynote of action."

"So, one and all, we rejoice in this end," said Cho-koh-tung.

"And our aim shall be to give all the joy that we can," exclaimed the pop-gun.

"I move we pass a resolution to that effect," said the express-wagon.

"Don't "put the cart before the horse," 
grumbled the hobby. "I think I should have made the motion."

"Miss Dolly," continued the express-wagon, quite unmoved, "please hop upon the desk and lead the meeting."

"I should be chairman," murmured a small rocking-chair. "Dear me, your tongue can't stop waggin'."

"Any more than you can keep quiet," retorted the little express.

"Shall I keep the minutes of the meeting?" asked the Waterbury watch.

"No, the pencil will do that," replied the doll, "but you may second the motion."

"I rise to a point of order!" cried a tack in the tool-chest.

"The tack has the floor," called the doll.

"I move that the wooden soldier keep away from the toy ship," said the tack, "or it may be taken for a Noah's ark."

" "That was the most unkindest cut of all,", said the hatchet sharply.

"I should say so," sighed a spool.

"I thought I would join the navy," replied. 


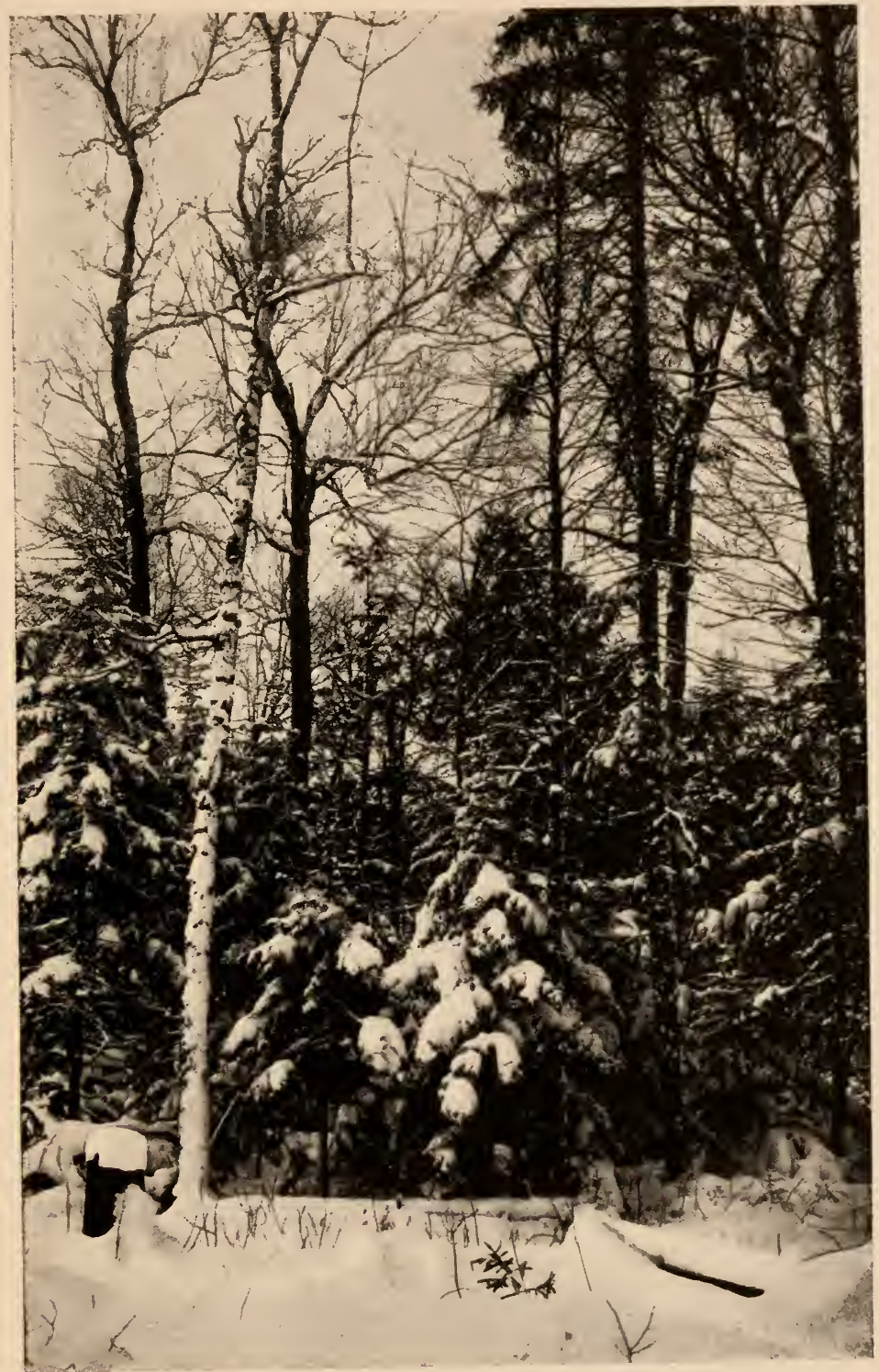

CHRISTMAS IN THE WOODS 



\section{THE CHRISTMAS TREE}

the wooden soldier stiffly, "for where there is a tub, there must be water."

"I fear you would run aground in me," said the tub.

"That was a dry remark," observed the book.

"We have forgotten our good resolution," said the doll.

"All in favor of it say "Aye,", called a needle in the work-basket.

"And all opposed say 'Nay," " whinnied the hobby-horse.

"I appoint the wooden soldier sergeant-atarms to keep order," said the doll. "You must stop your cutting up."

"I'm not," snapped the scissors.

"I hear them talking upstairs," warned the wooden soldier, sentried by the door, "and Father is coming downstairs to put the cat out."

"Hurry back to your places!" cried the doll; while the wooden soldier hastily presented arms to help her off the desk.

What a whisking and scurrying there was, 
to be sure, though all that Father found was a demure little Christmas tree and some very sedate and innocent-looking toys. But Cho-kohtung smiled as she drooped her green boughs over the truant toys at her feet, the loving sharers in her joy of giving, which makes the joy of living.

She could hardly wait for the morrow, but Christmas really came at last. Then four children, almost before the dawn, flew pell-mell down the stairs and rushed upon the Christmas tree-one, two, three boys and a girllittle Emily and her brothers!

"Are you not glad that I came to you ?" Chokoh-tung eagerly asked of little Emily.

But Emily only laughed as she danced around the tree.

Again Cho-koh-tung asked wistfully, "Are you not glad that I came to town at Christmas time?"

But Emily only smiled as she held her doll close.

Then Cho-koh-tung would have shaken her ornaments until they tinkled and glittered for 
the children's delight; but no, it was the gifts that made them gay. And so Cho-koh-tung could not but be happy, too, though she longed to be even more beautiful than she was.

And when evening came, and the family was gathered around the long, bright table, Father slipped into the parlor and flashed light after light from the colored tapers over the tree. There she stood, a blaze of splendor, blinking as she used to blink when the sunlight sparkled on her snow-laden boughs. Yes, Cho-koh-tung used to wear a mantle of snowermine and a crown of ice-diamonds and stand like a princess on an alabaster floor; yet still was she a beautiful princess of the forest, wearing her green velvet gown, and come to town at Christmas time to make the children glad! Father drew up the shades that passersby might see her beauty, and then rolled back the sliding-doors.

"Are you not glad that I gave up cones for Christmas candles?" she asked, as little Emily clapped her hands for joy; and Emily laughed, not that she heard what the balsam was saying, 
but was not this the prettiest Christmas tree in all the world!

Then the balsam-fir longed to cast off her glittering garment and make herself known; yet after all, it was the tinsel robe and taper crown that gave the children joy.

"Why does the tree wear a star?" asked Archie of his father.

Then Father told why the tree wore a star, in the story of the Christ-child, Who left His heavenly home to make us good and glad, because "God so loved the world."

"And now who will tell what is the real fruit of a Christmas tree?" he asked.

"The golden star," said Emily, softly.

"Gifts," shouted the boys, "gifts!"

But Father shook his head.

Merrily passed the holiday week. Children from blocks around came in to see the pretty Christmas tree, and poor children were brought in to share the gifts. By New Year's night the candles were burned to their sockets : Cho-koh-tung's task was done.

That New Year's night, when the house was 
very still, and for the last time Cho-koh-tung stood in her gay trappings, a little one in white stole softly down the stairs, and Emily, by the light of the lamp without, came swiftly to the tree.

"I have been dreaming," she said, "and I dreamed of a beautiful evergreen tree that I found last summer in the forest."

The balsam-fir leaned closer. "O little Emily," she asked, "has my Christmas dress so changed me?"

Then Emily reached up and gathered the glittering boughs into her arms. "I am so glad, so glad!" she laughed. "Beautiful little fir tree, why did you come to me?"

"Who told me that Christmas time means happy time, and the giving of gifts?"

"Yes, I remember."

"And I thought, I have nothing to give. Did you think fir cones were pretty? Yet no, you would not have cared for them. Do they look like candles on a Christmas tree? Then the thought came-I tossed aside the dream of years of life, and having nothing else to give, 
I gave myself : for the real fruit of a Christmas tree is what lies back of gifts and giving."

"I know, I know," cried Emily, as the balsam-fir seemed to stoop and enfold her, "the real fruit of a Christmas tree is love !"

"And to love is to give."

Someone had missed Emily and was calling her.

"Good-night, little Christmas tree!" she said, lifting her sweet face once more to the glad touch of the evergreen bough.

"To-morrow she will think it all a dream," thought Cho-koh-tung, watching Emily pass through the dim light and up the dark stairs.

Then the Christmas tree, feeling no more the weight of her decorations, lovingly drooped her head, drooped it a little lower over her gay burden of children's joys. They, seemed to be falling from her, even as her winter burden of snow used to vanish in the sunlight. Was she sleeping?

"Sleep, little tree, sleep!" sang the wind without. 
"Will you wake me when morning comes?" she asked.

"Sleep, little tree, sleep!" said the wind soothingly.

"Sleep!" sang the drowsy snow.

"Nay, you will not wake me, and so I will not sleep," said the Christmas tree, cheerfully holding up her ornaments.

"Sleep, sleep!" everything seemed to whisper.

And so at last she fell peacefully asleep, dreaming that happy children were circling around her, clasping their Christmas gifts, yet loving her best of all; and still she seemed to be sleeping, in the morning light, when the little boys came to her for a last look on their way to school; and still she slept as Emily touched her lightly at parting.

"Last night I dreamed the prettiest dream of you and me," laughed Emily gaily.

But the Christmas tree did not hear.

An hour later, Mother and the maid took off the festive decorations and laid them away for another year and another tree. 
164 FOREST FANCIES

"This is the happiest Christmas that we have ever had," said the mother.

"The children were never so glad," answered the maid.

"I think," said the mother, smiling, "that the little fir tree brought to us the real spirit of Christmas." 



